
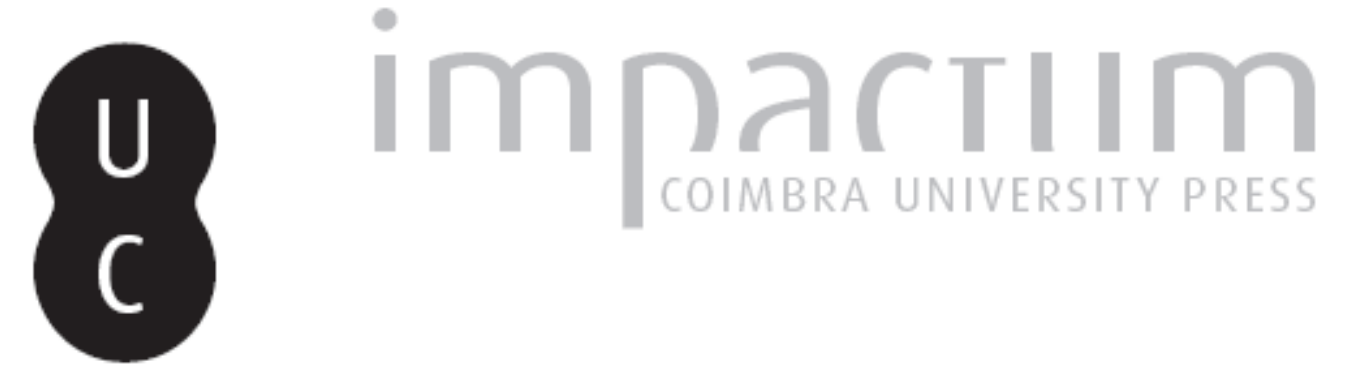

\title{
Secularização e laicidade: uma perspectiva histórica e conceptual
}

Autor(es): $\quad$ Catroga, Fernando

Publicado por: Imprensa da Universidade de Coimbra

URL persistente:

URI:http://hdl.handle.net/10316.2/43693

DOI:

DOI:https://doi.org/10.14195/2183-8925_25_2

Accessed : $\quad$ 26-Apr-2023 06:54:42

A navegação consulta e descarregamento dos títulos inseridos nas Bibliotecas Digitais UC Digitalis, UC Pombalina e UC Impactum, pressupõem a aceitação plena e sem reservas dos Termos e Condições de Uso destas Bibliotecas Digitais, disponíveis em https://digitalis.uc.pt/pt-pt/termos.

Conforme exposto nos referidos Termos e Condições de Uso, o descarregamento de títulos de acesso restrito requer uma licença válida de autorização devendo o utilizador aceder ao(s) documento(s) a partir de um endereço de IP da instituição detentora da supramencionada licença.

Ao utilizador é apenas permitido o descarregamento para uso pessoal, pelo que o emprego do(s) título(s) descarregado(s) para outro fim, designadamente comercial, carece de autorização do respetivo autor ou editor da obra.

Na medida em que todas as obras da UC Digitalis se encontram protegidas pelo Código do Direito de Autor e Direitos Conexos e demais legislação aplicável, toda a cópia, parcial ou total, deste documento, nos casos em que é legalmente admitida, deverá conter ou fazer-se acompanhar por este aviso.

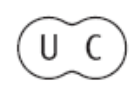



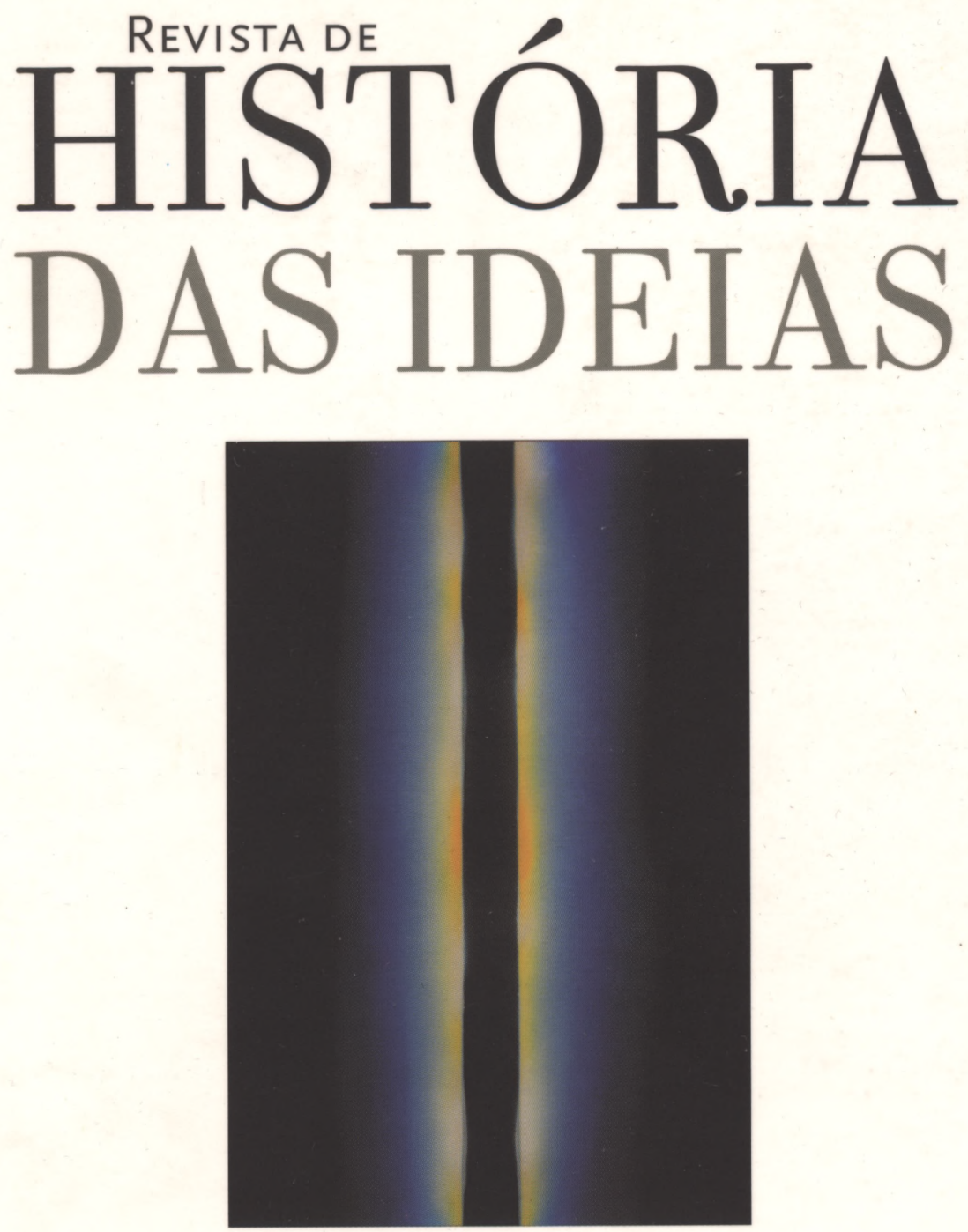

TOLERÂNCIAS, INTOLERÂNCIAS

\author{
Volume 25, 2004
}

INSTITUTO DE HISTÓRIA E TEORIA DAS IDEIAS

Faculdade de Letras da Universidade de CoImbra 


\section{SECULARIZAÇÃO E LAICIDADE Uma perspectiva histórica e conceptual}

Este ensaio visa colocar o tema da tolerância na confluência de dois outros que consideramos essenciais para um melhor entendimento das suas variadas concretizações históricas, em particular nos países de maior influência católica do Sul da Europa. São eles a secularização e a laicidade, vocábulos amiúde apresentados como sinónimos ${ }^{(1)}$. Mas, uma análise conceptual e diacrónica revela as suas diferenças, embora também detecte a existência de um fundo comum (mormente a demarcação do temporal em face do religioso, do privado em face do público) e um análogo cruzamento com a valorização dos direitos fundamentais do homem, a começar pela liberdade de consciência e de pensamento. Pelo que tal associação não deve surpreender, pois esta problemática apareceu na mesma conjuntura em que surgiu a da tolerância moderna (Pierre Bayle, Locke), debate que não só lhe circunscreveu critérios e limites de julgamento, como levantou questões ainda hoje em aberto, porque não cumpridas.

* Faculdade de Letras da Universidade de Coimbra.

(1) Já estudámos as relações entre a secularização e a laicidade em: Fernando Catroga, A Militância laica e a descristianização da morte em Portugal, vol. 1, Coimbra, Faculdade de Letras, 1988; "A questão religiosa e o laicismo em Portugal", Análise Social, n. ${ }^{\circ}$ 100, vol. 24, 1988, pp. 211-274; "Secularização e história", AA VV., XII Encontro de Professores de História da Zona Centro, Coimbra, s. ed., 1994, pp. 53-64. 


\section{A história das palavras}

Segundo Giacomo Marramao, a secularização é "uma das expressões chave do debate político, ético e filosófico contemporâneo"(2). Porém, aqui, não o iremos analisar em todas as suas vertentes, pois interessa-nos, tão-só, aquele que tem sublinhado o facto de o conceito referenciar o caminho que veio a desaguar na Modernidade, provocando a progressiva autonomização da razão, da natureza, da sociedade e da política, assim como a imanenticização dos fundamentos da ética e da liberdade, e a paulatina separação da esfera pública da privada. Percurso exemplarmente tematizado nas críticas que Kant lançou à especulação metafísica tradicional e bem expresso tanto na redução da ideia de natureza ao reino da fenomenalidade físico-matemática, como na relevância dada ao papel da acção do homem na construção do seu próprio destino ${ }^{(3)}$. Ora, sendo a perspectiva escolhida dominantemente histórica, uma nova pergunta prévia se impõe: qual a origem etimológica do termo "secularização"(4)?

\section{De "século" a "secularização"}

De acordo com alguns estudiosos, a carga semântica da palavra saeculum (de secus ou sexus) ainda requer novas exegeses histórico-antropológicas, em ordem a explorar-se as possíveis ligações linguísticas

(2) Giacomo Marramao, Cielo e terra. Genealogia de la secolarizzacione, Roma-Bari, Laterza, 1994, p. 7. Sobre a pertinência do conceito, numa óptica de renovação do pensamento teológico católico, veja-se Juan José Tamayo, Fundamentalismo y diálogo entre religiones, Madrid, Editorial Trotta, 2004, p. 26 ss.

(3) Cf Miguel Baptista Pereira, "Iluminismo e secularização", Revista de História das Ideias, vol. 4, t ${ }^{\circ}$ II, 1982, p. 499.

(4) Os estudos clássicos sobre o tema são os de Hermann Lübbe, Säkularisierung. Geschichte eines ideenpolitischen Begriffs, Freibourg-München, Alber, 1965, e de H.-W. Strätz, "Säkularisation, Säkularisierung II. Der kanonistische und staatskirchenrechtliche Begriff", O. Brunner, W. Conze e R. Koselleck (ed.), Geschichtliche Gundbegriffe. Historisches Lexicon zur politisch-sozialen Sprache in Deutschland, t. ${ }^{\circ}$ V, Stuttgard, Klett-Cotta, 1984, pp. 792-809. Veja-se, também, Karel Dobbelaere, "Secularization: a multi-dimensional concept", Current Sociology, vol. 29, n. ${ }^{\circ}$, 1981, pp. 3-14. 
nela implicadas, em particular as existentes entre sexo, geração, idade do homem, tempo de governo, duração da vida, período máximo de cem anos, etc. Por outro lado, quanto a esta última significação, não se pode confundir a sua sagração, no Império Romano, como "lapso de tempo", com a sua posterior cristianização, que a entendeu como tempo "mundano" (weltlich), e ter-se-á igualmente de relevar o trânsito de saeculum para o seu uso na acepção de "cem anos" (Jahrhundert) $)^{(5)}$, relembrando que, apesar de se lhe poder reivindicar uma herança etrusco-romana, as necessidades de periodização da história somente impuseram esse critério nos séculos XVI e XVII.

Tudo isto contribuiu para que o conceito de secularização tenha aparecido na confluência de várias tradições, as quais, segundo Reinhart Koselleck, podem ser assim resumidas: a que resultou do diálogo entre a herança greco-romana e o cristianismo, legado que o direito canónico virá a recolher, para denotar a separação entre o estado de clero e o de secular ou de leigo; a que resultou da relativa diferenciação entre o domínio político e o espiritual, justificada através de argumentos de cariz jurídico-político; e a que foi filha da experiência moderna de tempo, cujo primeiro grande momento forte se deu com a Revolução Francesa, e que, em termos teoréticos, se estribará em argumentos de cunho historicista. Como é lógico, o que, aqui, por razões analíticas, será distinguido, não raro se miscegenou nas suas experiências históricas específicas.

Relembre-se que, no cristianismo, a palavra saeculum foi aplicada na Vulgata (São Jerónimo), para traduzir o grego kósmos numa acepção negativa: o "momento presente", este "século", em oposição a eternidade, ao futuro - o "reino" prometido por Deus. Por isso, ela virá a ser utilizada não só para caracterizar o mundo dos pagãos, mas também para exprimir o gradual desfasamento, no interior do cristianismo, de duas categorias de fiéis: a dos clérigos e a dos crentes. Segundo alguns outros, a primeira tentativa para clarificar a destrinça entre os "iniciados" e os "profanos" terá sido feita por Lactâncio (século IV), e sabe-se que São Vito, na linha de Estácio Afro, apelidou os autores pagãos de saecularii ${ }^{(6)}$. Por sua vez,

(5) Cf. Reinhart Koselleck, Aceleración, prognosis y secularización, Valencia, Pre-Texto, 2003, p. 41, nota 5.

(6) Cf. Fernando Ferrarotti, Una Fé sin dogmas, Barcelona, Ediciones Peninsula, 1993, pp. 110, 114. 
a doutrinação de Santo Agostinho justificou, de uma maneira mais profunda e convincente, a dicotomia (e a oposição) entre as duas Cidades, ou melhor, entre o espiritual (geistlich) e o secular (weltlich), transfundo histórico que, "através de numerosas transformações e metamorfoses, estruturou, como mostrou Gilson, a história ocidental"(7). Quer tudo isto dizer que a aplicação do termo saeculum, no sentido de "mundo" oposto ao do "clero", foi contemporânea - como salientou, entre outros, Jean Gaudemet ${ }^{(8)}$ - do trabalho de delimitação dos dois géneros de vida, assim como da definição das obrigações e do estatuto de clérigo (que data dos séculos IV e V).

Longa é a história desta palavra. A sua origem remete para o radical $k e l$, que teve sequências em várias línguas europeias, com a significação de "cortar", "golpear", "bater", "pau", "vara", "pedaço de madeira". Em grego, deu Klêros, que referenciava "o objecto que se lançava para decidir o sorteio, o dado, e, por metonímia, o sorteio, o lançamento de dados, o tirar à sorte"(9). Assim, o vocábulo Kláo (dividir) era utilizado, desde Homero, para designar o fragmento de pedra ou o troço de madeira que se usava para tirar as sortes, a fim de se auscultar a vontade dos deuses. E, porque a terra e o solo, provavelmente no marco de uma exploração agrícola colectiva, se dividiam tirando sortes, Klêros também adquiriu o significado de "parte", "pedaço de terra", "quinta" e, finalmente, de "herdade". Ainda por extensão metonímica, o verbo correspondente é klēróo,, "sortear"; Klēronomía, de Klêros, e némō ("distribuir"), é o "sorteio", a "distribuição por sorte" enquanto actividade, e, daí, o "lote" atribuído, a "herança"; enquanto que Klēronómos é aquele a quem corresponde um Klêros: o "herdeiro"; synklèronómos, por sua vez, é o "co-herdeiro", e Klēronomeo remete para "ser herdeiro", "herdar".

Estes termos serão aplicados nas traduções gregas do Antigo Testamento. Também aqui há referências à prática de se tirar sortes (gơralal), a fim de se conhecer a vontade de Deus. O sumo sacerdote levava os

(7) Reinhart Koselleck, ob. cit., p. 44. Koselleck refere-se à obra de Étienne Gilson, Les Métamorphoses de la cité de Dieu, 1952.

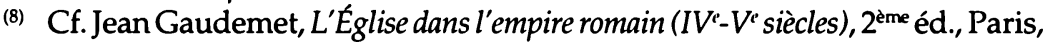
Sirey, 1958, p. 99 ss.

(9) Telmo Verdelho, "Clérigo/Leigo: nota filológica", Luís Machado Abreu (coord.), Variações sobre o tema anticlerical, Aveiro, Universidade de Aveiro, 2004, p. 22. 
"urim e tumim" ("luz e direito") na investidura sacerdotal (Ex 28, 20; Lv 8,8) e usava-os para averiguar a vontade divina. E, nas bênções de Moisés (Dt. 33), esta auscultação por meio de sortes e a administração da lei de Deus ( $t \bar{o} r a ̄ h)$ estão estritamente ligadas.

Ainda na perspectiva que agora particularmente interessa, também se sabe que, nos textos de Qumran, o conceito de sorte ( $g \bar{o} r \bar{a} l)$ adquiriria uma importância capital, designando, igualmente, o destino que foi fixado de antemão por Deus e, portanto, a pertença a Deus (os filhos da luz, os espíritos do conhecimento, etc.), ou a Belial (os filhos das trevas e de seus espíritos). Mas, frequentemente, também referenciava "classe", "posição", "hierarquia".

Surge igualmente a ideia (que o Novo Testamento encorporará) de que a comunidade participa da sorte dos anjos. Acreditava-se que estes estão nela presentes, ao mesmo tempo que se aceitava que os eleitos podiam ser chamados santos na terra, sugerindo-se, assim, que também a comunidade recebeu os bens salvíficos próprios dos anjos. A escolha dos noviços decidia-se de acordo com o resultado das sortes (no sentido estrito), que se tiravam no conselho da assembleia, embora não se saiba se se tratava, realmente, de um sorteio, ou de um exame feito com a finalidade de estabelecer a sorte que Deus atribuiu a cada um deles, qualidade que podia ser somente atestada pela análise do seu comportamento terreno.

Por sua vez, no Novo Testamento, encontra-se Klêros, na acepção de "sorte", onze vezes, e, em sete delas, tem esse significado específico; nas restantes, remete para "parte", "herança", "herdar".

Se se quiser sintetizar todos estes sentidos, poder-se-á concluir que os textos sagrados da religião judaico-cristã utilizaram um grupo de conceitos, que serão relacionados com Klêros ("sorte", "herança"), para expressar o facto de o homem não se situar perante a Divindade com uma liberdade e independência totais. É que, por um lado, a sua vida tem um lugar determinado e participa, em grande medida, na história de Deus e da humanidade, e, por outro lado, d'Ele recebe, em sorte, certos dons e tarefas. Simultaneamente, o conteúdo do grupo de vocábulos em apreço tanto se refere a algo que tocou em sorte a alguém, como à solidez de uma promessa com efeitos jurídicos, o que lhe confere afinidades com o conceito de aliança. Dado que eles são sempre utilizados para nomear os dons que, essencial e originariamente, pertencem a Deus - sejam materiais (a doação da terra, ou de uma parte dela), ou espirituais 
(o reino, a vida eterna) -, eles servem, igualmente, para expressar as relações entre o homem e Deus, isto é, a vontade de Deus dar ao seu povo ou aos homens uma base de existência, graças à qual estes não estão dependentes da benevolência de outros homens.

Ora se, em alguns contextos, as ideias de sorte e herança são indissociáveis da comunidade de crentes, o certo é que também ganharam corpo outros significados, principalmente os associados aos de "classe", "posição" e "hierarquia", conotação que a gradual institucionalização do cristianismo como Igreja irá acentuar ${ }^{(10)}$.

Sabe-se que a forma latina clericus foi usada numa acepção distintiva e hierarquizadora da comunidade cristã a partir do século III. Mais especificamente: por Tertuliano (c. 160-240) em De idolatria (C. VIII); nas versões latinas das Homiliae in Jeremias (XI, 31) de Orígenes (185-232); por Clemente de Alexandria (†215), no seu tratado sobre o bom uso da riqueza (Quis dives salvetur, C. XLII) ${ }^{(11)}$. E São Jerónimo (c. 340-420) foi um dos primeiros pensadores cristãos a justificar a existência de duos genera christianorum: os clérigos e os leigos. Os primeiros viviam longe da agitação das regiões profanas, devotados ao serviço divino e despidos de quaisquer bens temporais, distanciamento simbolizado pela tonsura ${ }^{(12)}$, atitude de fuga saeculi que foi glorificada, entre outros, por Santo Ambrósio.

Tais transformações testemunham a "passagem da 'pusilla grex' cristã para uma organização eclesiástica mais fortemente hierarquizada"(13), isto é, revelam que a dimensão terrena da existência foi sendo recoberta por apreciações negativas, porque qualificada como o lugar do pecado e do tempo lapso e diminuído. E, de um modo mais neutral, século também começou a ser utilizado para designar as actividades sociais não orientadas para a salvação. Porém, qualquer que fosse o seu significado, é um facto que "la distinction des 'clercs' et du 'peuple' (laós)

(10) Nesta digressão sobre o vocábulo Klêros, seguimos a síntese feita por E. Eicher em "Herancia, suerte, parte", in Lothar Coenen, Erich Beyreuther e Hans Bietenhard, Diccionario teologico del Nuevo Testamento, vol. 2, Salamanca, Ediciones Sigueme, 1980, pp. 264-269 (agradecemos a indicação desta obra ao nosso colega e amigo Anselmo Borges).

(11) Cf. Telmo Verdelho, art. cit., p. 22.

(12) Jean-Claude Monod, La Querelle de la sécularisation de Hegel à Blumenberg, Paris, Jean Vrin, 2002, p. 18.

(13) Telmo Verdelho, art. cit., p. 22. 
ou des 'laïcs' marque la coupure interne à l'Église, entre ceux qui peuvent délivrer les sacrements et sont eux-mêmes sacrés à cette fin, à travers le sacerdoce, et la masse des baptisés qui font partie intégrante du corps de l'Église, mais n'ont pas le pouvoir sacré ou le 'charisme de l'Esprit saint' reçu au moyen du sacrement de l'ordre (pas plus qu'ils n'ont part à la vie selon la règle). La dualité clercs/laïcs introduit un balancement constant dans la définition même de l'Église, conçue comme communauté des fidèles et comme 'corps du Christ' selon le terme de Saint Paul (1 Cor. 12,12) et ultérieurement comme 'corps mystique dont le Christ est la tête' (selon la bulle Unam Sanctam de Boniface VIII), mais aussi comme institution temporelle hiérarchiquement constituée, dont la tête est le Pape"(14).

A dualidade receberá várias subdivisões ${ }^{(15)}$. No entanto, é indiscutível que, mesmo nestes casos, ganhou mais força a lógica hierarquizadora: 0 clero surge separado (pela ordenação) da massa dos crentes e superior a eles, porque dotado da potestas sacra, ou melhor, ele, enquanto "eleito" a quem coube a "sorte", afirma-se como o pastor do rebanho, a "luz" e o exemplo para o povo cristão. E, sublinhe-se, muitas das dissidências que o cristianismo irá sofrer - como foi a da Reforma e a do anticlericalismo moderno, ou mesmo as críticas das teologias da secularização e da libertação contemporâneas - tiveram (e têm) como origem a contestação feita a este estatuto de superioridade.

Por sua vez, a génese de vocábulos como secularizar e secularização ter-se-á dado em 1586 e 1559, respectivamente. O primeiro surgiu num contexto pejorativo - "il ne faut point secularizer" -, e o segundo apareceu aplicado ao arresto de bens da Igreja por parte da coroa. De facto, e como salientou H.-W. Strätz, o termo secularizar havia ganho curso no quadro de um ensaio teológico-literário de Pierre Crespet e, sobretudo, em escritos de Jean Papon e Pierre Grégoire, para representar a mudança do estado de clérigo regular para o de secular, enquanto que o de secularização teve mais eco depois de, no rescaldo da Guerra dos Trinta Anos (1618-1648), o duque de Longeville (representante francês nas conversações ligadas ao Tratado de Vestefália) o ter utilizado, em 1649,

(14) Jean-Claude Monod, ob. cit., pp. 18-19.

(15) Idem, ibidem, p. 19. 
para dar nome à acordada transferência de terras episcopais para mãos régias (tese enfatizada por $\mathrm{H}$. Lübbe). Todavia, se esta origem tem sido frequentemente assinalada, nem sempre se lembra que, naquela situação concreta, ela continha um claro acento antiprotestante: desejava-se impedir que os senhores territoriais protestantes continuassem com uma prática que eles mesmos apelidavam de "reforma", a saber: a confiscação de bens da Igreja Católica. A fim de o evitar, a paz de Vestefália decretou, para o solo do Império alemão, uma "situação global de tábuas que fixava rigidamente as quotas de propriedade eclesiástica e secular"(16).

Este sentido proprietista consolidar-se-á na sequência dos processos revolucionários modernos, impulsionados pelo exemplo da Revolução Francesa ${ }^{(17)}$. Com efeito, um pouco por toda a Europa, os novos poderes políticos procederão a amplas expropriações de propriedades, fundações e bens eclesiásticos, onda de choque em que, não raro, participaram os próprios soberanos dos Estados católicos. Por isso, o termo também passou a qualificar um acto jurídico, politicamente fundado, e que consistiu em reduzir ou em expropriar o domínio ou a posse de bens temporais da Igreja, para os destinar a fins exclusivamente profanos, em ordem a libertar-se a propriedade, subtraindo-a ao estatuto de bem de "mão morta" e ao poder da Igreja. E tudo isto dentro de uma lógica na qual o Estado moderno - ou melhor, o novo Estado-Nação - tendia a impor (de modos diversos, é certo) um conceito unicitário de soberania.

Seja como for, quer no âmbito do direito canónico, quer como acto jurídico ditado por razões políticas, é um facto que o processo secularizador foi acelerado pela acentuação da dicotomia entre o espiritual e o secular (geistlich/weltlich), dualismo que teve na doutrina agostiniana (século V) e, depois, no agostinianismo medievo, a sua teorização modelar $^{(18)}$.

Ligada à acepção canónica e, sobretudo, jurídico-política, consolidou-se uma outra, em consequência do desenvolvimento de uma maneira de pensar a que, desde os meados de Setecentos (Voltaire), se chamará

(16) Reinhart Koselleck, ob. cit., p. 42.

(17) A consigna "tous les biens de la nation doivent être sécularisés" anunciou a secularização revolucionária dos bens da Igreja (Novembro de 1789) e a Constituição Civil do Clero.

(18) Cf. Reinhart Koselleck, ob. cit., p. 44. 
"filosofia da história"(19). E, por diferentes ou antitéticas que venham a ser as várias ilações político-ideológicas que elas fundamentarão, será possível encontrar, em todas, uma crença comum: o convencimento de que as tarefas e desafios humanos "devem ser resolvidos no tempo histórico, com e através do próprio tempo histórico". Porém, agora, este já não se opõe a eternidade; antes a reclama para si, pelo que todos os dualismos e pares de opostos, de origem cristã, se dissolvem "debaixo deste pressuposto, apresentado como universalmente válido, segundo o qual o tempo mundano da história coloca problemas, mas também traz soluções". Por outras palavras: em vez da antítese imanência versus transcendência, a oposição entre passado e futuro passou "a ocupar o posto central" (20). Mudança que deu lugar a uma outra, expressa no aparecimento de uma mais forte tensão entre a ideia de passado e a de futuro, de onde promanou uma nova experiência de tempo, afirmada em articulação com os ideais de emancipação e de progresso, fruto da suposição da capacidade autonómica que a razão humana teria para dar transparência aos imperativos da razão prática e às leis da natureza, e para fazer aumentar o poder transformador do homem sobre o mundo. A isto se tem chamado "mundanização" (Verweltlichung), ou, talvez melhor, "temporalização". Em síntese: o postulado moderno da inteligibilidade do universo desaguou, naturalmente, neste outro convencimento: "Die Vernunft fordert die Säkularisierung" ("a razão fomenta a secularização")(21). Este é o título de uma obra que, em 1798, surgiu na Alemanha e que provocou polémica. Como a própria razão se historicizou, a secularização foi sendo apresentada como uma das condições necessárias para a consumação do sentido emancipatório da evolução da humanidade, acasalamento que terá reflexos no campo semântico em análise.

Na verdade, com a entrada no século XIX, o termo secularização, de acordo com o dicionário inglês de Oxford (1851), já referenciava uma moral que devia basear-se no bem-estar da vida presente, excluindo todo

(19) Cf. Fernando Catroga, Caminhos do fim da história, Coimbra, Quarteto Editora, 2002, passim.

(20) Reinhart Koselleck, ob. cit., p. 46.

(21) Cf. H. Blumenberg, La Légitimité des temps modernes, Paris, Gallimard, 1999, p. 28. 
o critério tirado da crença ${ }^{(22)}$. Sinal de que a dicotomia entre, por um lado, o religioso (aceite, à luz do relativismo histórico - que as filosofias da história justificavam -, como tendo sido necessário numa dada fase da diacronia humana), e, por outro lado, o secular, tinha dado lugar à dialéctica entre o passado e o futuro, teleologicamente sobredeterminada pela pressuposição da índole perfectibilista da natureza humana. Este novo modo de ver teve as suas primeiras aplicações na obra descristianizadora da Revolução Francesa e nas expropriações dos bens e domínios religiosos fixadas por um decreto napoleónico de 1803. Mas o seu significado especificamente filosófico-histórico e cultural foi imediatamente tematizado pela doutrinação dos Ideólogos e dos filósofos eclécticos, pois, na linha do seu líder, Victor Cousin (discípulo, nesta matéria, de Condorcet), começou-se a falar em "secularização da educação". Por sua vez, em Inglaterra, um seguidor do socialista utópico Owen - o futuro positivista e livre-pensador Jacob Holyoake - criou, em 1846, a London Secular Society, com o objectivo de lutar contra todas as formas de intervenção da Igreja e da religião, e a favor da secularização da sociedade. Análogos propósitos nortearam a Deutsche Gesellschaft für ethische Kultur e, mais tarde, a Deutsche Gesellschaft für Soziologie ${ }^{(23)}$, que, entre os seus membros, tinha Tönnies, pensador cuja conceptualização das diferenças existentes entre a "comunidade" (Gemeinschaft) orgânica e a "sociedade" (Gesellschaft) pós-tradicional, unida pelos laços contratuais, parece remeter para a oposição entre a sociedade religiosa e a sociedade secularizada ${ }^{(24)}$.

A partir de todas estas transformações, ganha sentido que, em Dezembro de 1880, o principal paladino da laicização do ensino em França - Jules Ferry (influenciado por Condorcet, Cousin, Guizot, Comte e Littré) fizesse radicar a secularização nesta herança histórica: "Il y a cent ans, on a sécularisé le pouvoir civil. Il y a deux-cents ans, les plus grands esprits du monde, Descartes, Bacon, ont sécularisé le savoir humain, la philosophie. Nous, aujourd'hui, nous venons suivre cette tradition: nous ne faisons qu'óbéir à la logique de ce grand mouvement commencé il'y

(22) Cf. Jean-Pierre Sironneau, Sécularisation et religions politiques, La Haye-Paris-New York, Mouton, 1982, pp. 77-78.

(23) Giacomo Marramao, Poder y secularización, Barcelona, Ediciones Peninsula, 1989, p. 23.

(24) Sobre tudo isto, veja-se Hermann Lübbe, ob. cit., pp. 44-49; Jean-Claude Monod, ob. cit., p. 25; Fernando Ferrarotti, ob. cit., p. 115. 
a plusieurs centaines d'années"(25). Havia, assim, a consciência de que se estava perante um fenómeno que Spenna Weilland caracterizou como "le passage - qui s'étend sur de nombreux siècles - $d$ 'une interprétation métaphysique de la réalité à une expérience et une interprétation de la réalité où le monde historique, social, humain, fini, constitue l'horizon de la responsabilité et de la destiné humaines"(26).

De facto, não se errará muito se se defender que o fenómeno da secularização só poderá ser compreendido desde que situado na longa duração ${ }^{(27)}$, embora se tenha de relevar as especificidades concretas decorrentes das incidências do processo não só no interior da Igreja, mas em todos os níveis (cultural, económico, político) da sociedade.

Como primeira nota, importa dizer que, a par da consolidação da diferença entre clérigo e secular, se foi acentuando uma oposição entre o poder espiritual e o poder temporal que, porém, se saldou na vitória do princípio Salus extra ecclesiam non est ${ }^{(28)}$ (sinteticamente: Extra ecclesiam nulla salus), preceito objectivado, como doutrina, no agostinianismo e, como aliança, no constantinismo político-religioso, isto é, no chamado cesaropapismo, ou no seu inverso, o hierocratismo. Como se sabe, esta evolução contraditava afirmações evangélicas - "A César o que é de César, a Deus o que é de Deus", ou "o meu reino não é deste mundo" -, instalando uma controvérsia que secundarizou, isolou ou aniquilou os que defendiam a autonomia entre o espiritual e o temporal, assim como uma atitude de tolerância em relação aos cismáticos e heréticos, ou às demais crenças.

\section{A secularização do ideal de tolerância}

Frequentemente, as análises sobre o conceito de tolerância sublinham a ambiguidade do vocábulo. Recorda-se a sua raiz indo-europeia - tol,

(25) In Jean-Claude Monod, ob. cit., p. 28.

(26) Spenna Weilland, "Qu'est-ce que la sécularisation", Herméneutique de la sécularisation, Paris, Aubier, 1976, p. 96.

(27) Sobre as origens mais remotas do fenómeno da secularização, veja-se G. de Lagarde, La Naissance de l'esprit lä̈que au déclin du Moyen-Age, 3 vols., Louvain, Éd. Nauwelaerts, 1970.

(28) Esta fórmula encontra-se numa carta de Cipriano, bispo de Cartago, decapitado em 258 por se opor ao culto imperial. 
tal, tla-e os seus derivados latinos, tollere e tollerare, onde tollere significa "levantar", "deixar" e, às vezes, "destruir", e tollerare remete para "levantar", "suportar" e "combater". Como se vê, já na sua origem se encontram dois sentidos opostos, um negativo ou passivo, e um outro positivo ou activo ${ }^{(29)}$, realidade que os dicionários virão a fixar. Em termos sintéticos, pode afirmar-se que o seu campo semântico recobre três acepções: a de "sofrer", "levar com paciência"; a de "permitir algo que não se tem por lícito, sem o aprovar explicitamente"; e a de "resistir", "suportar", sobretudo remédios ou alimentos ${ }^{(30)}$.

Naturalmente, o uso do conceito de tolerância não foi indiferente a esta polissemia; o que leva a que hoje se pergunte - na linha do que já Rabaut Saint-Étienne afirmou, na Assembleia Nacional francesa (22 de Agosto de 1789), quando propôs que o termo fosse retirado da Declaração dos Direitos do Homem, por ser uma palavra injusta, por designar "des Citoyens dignes de pitié, comme des coupables auxquels on pardonne"(31) - se ele pode exprimir ideais não passivos e reconhecer relações de alteridade e de diferença tecidas num plano de reciprocidade igualitária.

Não vamos tratar todas estas implicações, já que, dentro da economia da exposição, interessa partir do que é frequentemente reconhecido por um grande número de estudiosos: o conceito de tolerância, na sua faceta

(29) Cf. Claude Sahel (ed.), La Tolerancia, Madrid, Cátedra, 1993, p. 16 ss.; José Maria Vinuesa, La Tolerancia. Contribución crítica para su definición, Madrid, Laberinto, 2000, p. 62 ss; Diogo Pires Aurélio, "Tolerância/intolerância", Enciclopédia Einaudi, vol. 22, Lisboa, INCM, 1996, p. 179 ss.

(30) Cf. Antonio Vásquez Fernández, Tolerancia: debilidad o fortaleza?, Salamanca, Témpora Ediciones, 2003, p. 11 ss.

(31) Mais concretamente, Rabaut Saint-Étienne proclamou estas ideias: “Messieurs, ce n'est pas même la Tolérance que je réclame; c'est la liberté. La Tolérance! le support! le pardon! la clémence! idées souverainement injustes envers les Dissidents, tant qu'il sera vrai que la différence de Religion, que la différence d'opinion n'est pas un crime. La Tolérance! Je demande qu'il soit proscrit à son tour, et il le sera, ce mot injuste qui ne nous présente que comme des Citoyens dignes de pitié, comme des coupables auxquels on pardonne, ceux que le hasard souvent et l'éducation ont amenés à penser d'une autre manière que nous" (in Julie Saada-Gendron, La Tolérance, Paris, Flammarion, 1999, pp. 163-164). 
crítico-reflexiva, é um produto da Modernidade ${ }^{(32)}$. Mais especificamente, ele terá surgido para responder aos novos desafios levantados pela situação religiosa que a Europa conheceu a partir do Renascimento e da Reforma ${ }^{(33)}$. É verdade que não se ignora que houve atitudes tolerantes em períodos anteriores - Voltaire, no seu Tratado sobre a tolerância $(1763)^{(34)}$, considerou tolerantes gregos e romanos -, nem as possibilidades de se lhe encontrar fundamentos nos textos sagrados das três religiões do Livro. Por outro lado, também não se descura o contributo daqueles que podem ser apresentados como precursores do diálogo inter-religioso, desde Tertuliano, Lactâncio, Santo Atanásio, passando por Nicolau de Cusa (De pace fidei, 1453) ${ }^{(35)}$, momento de abertura de um caminho que, alguns séculos depois, encontrará na peça de Lessing, Nathan, o Sábio (1779), a sua expressão filosófico-literária mais marcante.

Porém, aquelas propostas estão quase exclusivamente confinadas à definição teológica da ideia de Verdade, tendo por destinatários os infiéis e os chamados hereges e cismáticos. Realidade que se agudizou com a Reforma e com as consequentes guerras religiosas que eclodiram no seio da própria cristandade (conceito que havia ganho corpo a partir do século IX). A prática do velho princípio Extra ecclesiam nulla salus foi impondo este outro: a unidade civil exigia a unanimidade da fé. E, com a relativa assunção de poderes autónomos por parte do Soberano (ou do Magistrado, de acordo com a linguagem do século XVII) acentuou-se o entendimento de que as divisões religiosas implicavam, simultaneamente, divisões civis e, por isso, rebeliões contra o Estado, perspectiva que irá encontrar na fórmula regalista francesa "une foi, une loi, un roi" uma das suas melhores sínteses.

Como a teologia oficial se esforçava por demonstrar, a heresia e a pluralidade de crenças tinham de ser criminalizadas e atacadas, tanto por razões sociais como salvíficas, pois representavam um perigo para

(32) Idem, ibidem, p. 117. Sobre a génese do tema no decurso do século XVI, consulte-se o clássico estudo de J. Lecler, Histoire de la tolérance au siècle de la Réforme, Paris, Albin Michel, 1994 (a 1. a ed. é de 1955).

(33) Cf. Julie Saada-Gendron, ob. cit., pp. 17-18.

(34) Cf. Voltaire, Tratado sobre a tolerância. Tradução e introdução de José M. Justo, Lisboa, Antígona, 1999, pp. 53-61.

(35) Cf. Nicolau de Cusa, A Paz da fé seguida de carta a João de Segóvia, Tradução e introdução de João Maria André, Coimbra, Minerva Editora, 2002. 
a sociabilidade e, ao mesmo tempo, impediam a consumação colectiva da escatologia. Daí, a necessidade de, no plano temporal, se castigar os heréticos, quer para salvar a sua alma por caridade, quer, ainda, por obediência aos deveres sociais, pugnando pelo bem-estar dos seus membros. Modo de pensar que se tornou sinónimo de teologia da guerra e de intolerância.

Sabe-se que as religiões cristãs reformadas também desenvolveram doutrinas análogas, embora, nos inícios da sua rebelião, Lutero tenha sido favorável à liberdade de pensar, recusando-se a confundir as Igrejas com o Estado. Situação que se alterou na Alemanha, com os seus principados a dividirem-se segundo o preceito "cujus regio ejus religio" já posto em prática na paz de Augsbourg (1555), mas só formulado em 1579. À sua luz, cada autoridade soberana detinha o poder de decidir acerca da religião praticada no seu território, de molde a garantir a homogeneidade política. Por sua vez, os dissidentes somente tinham o direito de se exilar depois de venderem todos os seus bens, regra que foi estendida aos calvinistas nos tratados de Vestefália( ${ }^{(36)}$.

Neste clima, as intenções dos que, como alguns humanistas (Marsílio Ficino, Pico de la Mirandola, Tomás More, Erasmo), propugnavam pela coexistência pacífica entre as religiões, ficaram submersas pelas pregações de uma intolerância teológica que recorria à espada da intolerância civil para atacar a coabitação de indivíduos e Estados com confissões diferentes, ainda que crentes no mesmo Deus ${ }^{(37)}$. E foi para responder a este caos que alguns intelectuais procuraram um credo mínimo, capaz de possibilitar a tolerância (religiosa e civil). No entanto, uma pergunta tem de ser feita: quais as novidades trazidas pela nova problematização deste ideal, quando comparadas com a dos seus precursores? A diferença é esta: mesmo no século XVI, muitos dos apologistas da tolerância não eram leigos nem anticlericais, como o serão, por exemplo, no tempo das Luzes. Os debates ocorreram sempre entre cristãos, embora desavindos, e o seu objecto incidia, sobretudo, na interpretação da Bíblia. Só depois é que a discussão se libertou do seu horizonte dominantemente teológico, numa correlação directa com o movimento que apontava para a secularização dos alicerces da ética, da sociedade e do Estado.

(36) Cf. Guy Saupin, Naissance de la tolérance en Europe aux temps modernes, Rennes, PUR, 1998, p. 189.

(37) Cf. Julie Saada-Gendron, ob. cit., pp. 19-20. 
A representação que a Igreja fazia de si mesma como instituição, bem como os seus principais pensadores - como Santo Agostinho, ou mesmo Tomás de Aquino - não franqueavam este caminho. Quanto ao primeiro aspecto, sublinhe-se que ela se foi afirmando, perante o poder político, como uma societas iuridice perfecta de direito divino, independente e soberana. Promanando todo o poder de Deus, a sua sede localizava-se nos descendentes de Cristo, organizados como Igreja, pelo que àquele cabia "apenas uma tarefa subsidiária de guardião da verdade objectiva e defensor da fé, funcionando como braço secular para a perseguição e punição dos hereges, apóstatas e cismáticos". Daí que se reivindicasse, com particular ênfase, a "libertas ecclesiae"(38).

Este estatuto foi preparado por posições como as do bispo de Hipona, sobretudo quando, na sua correspondência (carta a Bonifácio, por exemplo) e na sua polémica contra os donatistas, justificou o dever que o Soberano tinha - à luz da concepção paulina non est potestas nisi a Deo de perseguir os heréticos. Deste modo, se a intolerância foi má quando afectou os cristãos (como aconteceu nos primórdios do cristianismo), ela seria justa e acto de caridade, desde que ao serviço da ortodoxia. Consequentemente, não devia ser apreciada como uma coacção, mas como um instrumento escatológico, porque acção libertadora das más influências do mundo sensível, ou melhor, dos hábitos, costumes e educação que impediam o acesso à luz da Verdade ${ }^{(39)}$.

Tomás de Aquino não foi tão longe e, na sua Suma Teológica (1266-1272), considerava a heresia como um erro, uma errância e um crime contra o direito. Por conseguinte, seria legítimo aplicar-lhe uma sanção tanto espiritual (a excomunhão) como temporal (a morte). Mas também reconhecia que, se Deus, bom e omnipotente, permitia a existência de males no universo, a supressão destes últimos aniquilaria, simultaneamente, uma parte do bem. Logo, e em termos semelhantes, o Príncipe devia tolerar certas infidelidades. É que, se, em si mesmas, estas são um mal, a sua relativa tolerância possibilitava evitar males maiores (como as desordens civis) e garantir certos bens.

(38) Jónatas Eduardo Mendes Machado, O Regime concordatário entre a "libertas ecclesiae" e a liberdade religiosa. Liberdade de religião ou liberdade da Igreja?, Coimbra, Coimbra Editora, 1993, p. 11.

(39) Cf. Julie Saada-Gendron, ob. cit., pp. 87-88. 
É indiscutível que esta concepção pragmática se inscrevia num horizonte dominantemente teológico. Bem vistas as coisas, ela era proposta como uma paciente outorga por parte de quem se considerava instalado na posse da Verdade. E, perante esta - definida como uma norma objectiva e universal, e enunciada por uma instância eclesiástica -, a tolerância só podia ter o valor de uma necessidade prática e temporária. Por outras palavras: ela manifestava uma espécie de sofrida concessão que a Verdade fazia ao erro culpável, pelo que a sua razão de ser era mera condição benévola, necessária à organização da Cidade, situação que, porém, somente se justificava enquanto o erro não fosse assimilado ${ }^{(40)}$.

Todavia, não se pode menosprezar o facto de que, em muitos casos, para além das posições oficiais das Igrejas e dos Soberanos, o convívio e a relação quotidiana entre indivíduos com credos diferentes terem dado vida a uma "tolerância informal" que permitiu, não só coabitações, como, em muitos casos, miscegenações culturais e étnicas ricas de significado humano.

\section{A "tolerância civil"}

É indiscutível que as cisões na cristandade e a intensificação dos contactos do Ocidente com outras civilizações obrigaram ao reequacionamento da questão. E esta maior abertura à alteridade será feita a partir de três ângulos essenciais (amiúde inter-relacionados): a hermenêutica bíblica, a natureza humana e as exigências da sociabilidade.

Como é característico das religiões do Livro, o texto que pode condenar também pode ser invocado em sentido diferente. Deste modo, entende-se que se detecte, neste debate, uma tendência que os séculos posteriores (até hoje) continuarão a manifestar, e que é esta: enquanto as leituras de cariz literal são, comummente, postas ao serviço de posições integristas ou fundamentalistas - já Pierre Bayle, na conjuntura da revogação do Édito de Nantes, afirmou: "tout sens littéral qui contient l'obligation de faire des crimes est faux" -, as de teor mais simbólico, ou as que relevam a mediação humana e histórico-social (a língua dos profetas, as traduções, o público alvo, a polissemia das palavras), denotam uma

(40) Cf. Idem, ibidem. 
maior disponibilidade para a aceitação de uma análise que hoje chamamos hermenêutica, mesmo que feita em nome de um ideal de reconciliação, concórdia ou unificação futura.

Esse já tinha sido o anelo da doutrinação dos que, sob um fundo irenista, haviam defendido a instrução dos heréticos e não a sua repressão, à luz de um recentramento inspirado num credo mínimo, isto é, numa fé simples, viva e depurada de subtilezas teológicas. Tal foi o caso de Marsílio Ficino e de Pico de la Mirandola, humanistas que pretenderam restaurar a paz religiosa, as humanidades e a livre discussão. Por sua vez, Nicolau de Cusa sonhou com o estabelecimento de um credo universal, acordado por um areópago de sábios, numa antevisão do diálogo inter-religioso. Seja como for, é um facto que todos estes ideais de tolerância oscilaram entre um desejo inclusivista e de assimilação - estribado na crença de que a unanimidade da fé viria a perdurar, em paz, na unicidade de uma religião querida por Deus ${ }^{(41)}-$, e, como é o caso nos passos mais explícitos do pensamento cusano, o "reconhecimento da dinâmica inscrição e promoção da paz dentro da própria fé e das diversificadas crenças que são as suas múltiplas manifestações" ${ }^{\prime(42)}$.

Descendo ao que, nesta querela, melhor pode mostrar a desenvolução do processo secularizador, frise-se que, com o Humanismo, medrou, como arma argumentativa, o método histórico-filológico. De facto, e não obstante a sua aplicação privilegiada ter incidido sobre os textos greco-latinos, ele também se estendeu aos sagrados ou aos ligados à história da Igreja. Objectivamente, esta atitude acarretará consequências secularizadoras, como foi o caso da demonstração da falsidade - efectuada por Lourenço Valla, em 1440, no seu De falso credita et emertita Constantini donatione - da célebre doação de Constantino (280-337), fonte onde se escudava a aliança entre a Igreja e o poder temporal.

Factor ainda mais importante foi o desenvolvimento de uma análise não literal da Bíblia, precursoramente feita por Isaac La Peyrère, Uriel da Costa e Hobbes, mas que encontrará em Espinosa o seu mais influente cultor. Foi propósito do autor do Tratado teológico-político (1670) mostrar que o Livro não ensina qualquer dogma especulativo, pois somente contém

\footnotetext{
(41) Idem, ibidem, p. 23.

(42) João Maria André, "Introdução", Nicolau de Cusa, ob. cit., p. 15.
} 
ensinamentos morais - praticar a justiça e a caridade - acessíveis a todos. Interpretar o texto por ele mesmo (scriptura sola) e buscar o seu sentido, e não a verdade, permitiria desfazer as "invenções", os "julgamentos arbitrários" e as "superstições", desconstruindo as interpretações dogmáticas das Escrituras, que fomentam uma flutuactio animi no povo, relevando, ao invés, o trabalho de construção histórica. Assim sendo, Espinosa reservava somente à razão o cuidado com a procura da verdade ${ }^{(43)}$, o que permitia perceber que, liberta dos dogmas teológicos, que revestiam a sua interpretação, a Bíblia nada continha de oposto à liberdade de pensar $^{(44)}$. E, como se sabe, para ele, impedir a liberdade de pensar significava demolir a piedade e a paz do Estado, e esquecer que "a fé consiste menos em actos exteriores do que na simplicidade e sinceridade da alma, e que esta provém, não do soberano, mas de si mesma"(45).

Moderna é, igualmente, a defesa da tolerância radicada em imperativos de índole moral. Esta centração secundarizou o debate acerca da Verdade, colocando-o na sinceridade das convicções (mesmo que erradas), ou melhor, no cerne da consciência. Foi o passo dado por Bayle, numa espécie de secularização da doutrina protestante do livre arbítrio. A consciência constitui, para ele, o único critério, pelo que a concretização da índole universal da luz natural se dá sempre num particularismo ligado à vida interior. $\mathrm{E}$, sem aceitar que todas as opiniões fossem equivalentes, ou que a verdade não existia, ele punha toda a ênfase na necessidade de valorizar a consciência, dando cidadania ao erro sincero; o que situou a práxis em ditames que ultrapassam a via intelectualista das ideias claras e distintas. Nesta óptica, a religião recebeu uma definição que, contra os dogmatismos teológicos, relevava a subjectividade, pois aquela constituía uma persuasão interior da alma em relação a Deus, que somente podia ser julgada e apreciada à luz da qualidade moral da adesão $^{(46)}$. Neste contexto, ter-se-ia de concluir que um erro, desde que acreditado, sinceramente, como verdade, seria mais útil do que uma prática imoral da Verdade, feita em nome da religião.

\footnotetext{
(43) Cf. Espinosa, Traité théologico-politique, Paris, Flammarion, 1965, p. 138 ss.

(44) Cf. Julie Saada-Gendron, ob. cit., p. 20.

(45) Raymond Polin, "Introdução", John Locke, Carta sobre a tolerância. Trad. de João da Silva Gama, revista por Artur Morão, Lisboa, Edições 70, 1996, p. 81.

(46) Cf. Julie Saada-Gendron, ob. cit., p. 97.
} 
Sendo a consciência um juiz ou um tribunal interior, pode então dizer-se que ela eticiza (Kant) a liberdade de pensamento, bem como a própria vivência religiosa. E este postulado, imbuído de autenticidade existencial, conduzirá a um dos momentos mais fortes na consolidação da ideia moderna de tolerância que a citada peça de Lessing, Nathan, o Sábio (1779), consagrou. Pondo em diálogo três representantes da religião do Livro, em vez das pretensões de todos à Verdade absoluta, sublinhar-se-á a existência de um fundo comum: o facto de todos perfilharem religiões do amor, filialmente transmitidas. Com isso, Lessing deu voz aos sonhos iluministas (e maçónicos) de fraternidade universal (inclusiva das diversidades religiosas, nacionais ou sociais), sem ter do universalismo uma concepção excessivamente holista e abstracta.

$\mathrm{Na}$ mesma conjuntura, e sob o impacto da discussão apostada em ultrapassar as guerras de religião que minavam a Europa e as Ilhas Britânicas, Locke meditou sobre o tema durante algumas décadas. Pelo que a Carta sobre a tolerância (1689) é, não só o ponto de chegada do seu percurso intelectual, como indicador das grandes preocupações políticas, religiosas e filosóficas da época. Com efeito, são conhecidas as confluências de teses ${ }^{(47)}$ e acontecimentos que, ecoando ou não no seu escrito, lhe dão um valor de testemunho; o que o torna inseparável, quer de factos como a revogação do Édito de Nantes, quer do passo positivo, mas insuficiente, que foi dado, em Inglaterra, com a aprovação do Tolerance Act (1688).

Por outro lado, para além das dívidas de Locke em relação ao texto bíblico e aos inúmeros autores que, antes dele, haviam escrito sobre a tolerância, deve ser sublinhada a influência directa das posições, mais liberais em religião, de movimentos como os latitudinários de Oxford - que se opunham à tese calvinista da predestinação e à sua tirania -, os platónicos de Cambridge e os remonstrantes holandeses, com os quais conviveu durante o seu exílio, conjuntura em que fixou o seu pensamento definitivo sobre a matéria.

(47) Inúmeros textos surgiram no século XVII sobre a tolerância (e intolerância). Sintomaticamente, os picos das suas edições ocorreram entre 1646-1647, 1670-1671, 1685-1689. Cf. Bernard Cottret, “1598-1688. De L'Édite de Nantes à la Glorieuse Révolution. Concorde, liberté de conscience, tolérance", Antoine Capet e Jean-Paul Pichardie (coord.), La Naissance de l'idée de tolérance (1660-1689), Rouen, PUR, 1999, p. 10. 
Sem deixar de enfatizar a liberdade de consciência - que considera iluminada pela vontade divina -, o autor do Ensaio sobre o entendimento humano valorizará, sobretudo, as demonstrações de cariz racional - ainda que a partir dos ensinamentos do mundo dos sentidos -, em ordem a colocar o conceito de tolerância, não como um problema religioso (ou inter-religioso), ou mesmo exclusivamente político, mas mais como uma exigência para melhorar a organização da Cidade, tendo em vista o respeito das opções subjectivas dos indivíduos, em harmonia com a prossecução do "bem comum civil", função última do Magistrado. Em suma: a sua argumentação baseia-se em concepções distintas acerca da origem, do fim e do objecto da associação religiosa e da sociedade política.

Locke deu uma origem contratualista a esta última e fixou-lhe, como finalidade, a paz civil, ou melhor, a realização do bem comum. Pelo que ao Magistrado é atribuída, como poder delegado, a capacidade de fazer a lei e de a impor, em caso de necessidade, através da "coacção". Por palavras suas: trata-se de uma "sociedade de homens constituída unicamente com o fim de conservar e promover os seus bens civis" (48), isto é, a protecção da vida, a liberdade e a propriedade privada. Por isso, seria de boa política perceber que o caminho que conduz ao céu não cabe ao Estado, e levar em conta que tudo o que atente contra a consciência nunca poderá culminar na bem-aventurança, tarefa exclusiva do foro íntimo.

A Igreja não podia considerar-se sociedade perfeita ou sociedade eterna, mas societas spontanea, ou melhor, "uma sociedade livre e espontânea", dentro da qual, porém, ao contrário da sociedade política, ninguém irreversivelmente perde a liberdade de escolha, pois a sua razão de ser radica nos direitos inalienáveis, imprescritíveis e irrenunciáveis dos indivíduos associados como crentes numa mesma religião, a fim de promoverem o culto público ao seu Deus e de garantirem a sua salvação.

Quer isto dizer que as religiões e o Estado tinham de ser instituições absolutamente distintas e separadas, pelo que, tanto a fusão da primeira com a segunda, como o seu inverso, só poderiam produzir intolerância e impedir a paz civil. Por conseguinte, o Magistrado, para seu próprio benefício, devia ser tolerante, pois a liberdade de consciência nunca poderá ser coagida em matéria de fé, tipo de acção que gera sempre

(48) John Locke, ob. cit., p. 92. 
efeitos contrários aos pretendidos, devendo as fronteiras da sua actuação situar-se, tão-somente, nos efeitos externos da religião que pudessem colidir com os princípios que norteavam a prossecução do bem comum.

Perguntar-se-á: significa isto que Locke foi um apologista de um ideal de tolerância sem limites? William Poppe, tradutor da Carta para inglês, escreveu a célebre frase, durante muitos anos atribuída ao próprio Locke: "é da liberdade absoluta, da justa e verdadeira liberdade, da liberdade igual e imparcial, que temos necessidade"(49). Ora, várias são as obras em que este se demarcou da absolute liberty, através da eleição de um conjunto de intoleráveis, balizados pelas ameaças que representavam para o contrato social. São eles: os que professam dogmas opostos ou contrários à sociedade humana e aos bons costumes, pondo em causa "a conservação da sociedade civil"; os que "atribuem aos fiéis, aos religiosos, isto é, a si próprios, nos assuntos civis, algum privilégio e poder de que não goza o resto dos mortais" e que, por conseguinte, são intolerantes para todos os que não partilham a sua fé; os que pertencem "à igreja em que cada um passa, ipso facto, ao serviço e à obediência de um soberano estrangeiro".

Como o contexto facilmente mostra, esta última posição visava - na linha do que tinham pensado outros tolerantes, como Milton e Marvel os católicos, ou melhor, os "papistas". A restrição não era de ordem teológica, mas exclusivamente política. Admitir os que não estavam dispostos a respeitar o contrato social, seria introduzir, no interior do seu território e cidades, "uma jurisdição estrangeira", e possibilitar que "entre os seus cidadãos se alistassem soldados para combater o Estado. Para este facto", precisava Locke, "a distinção inútil e capciosa entre a Corte e a Igreja não traz remédio algum, porque tanto uma como outra estão igualmente sujeitas à soberania do mesmo homem, que pode aconselhar aos membros da sua igreja tudo o que lhe agradar, tudo o que é espiritual ou se ordene ao espiritual, e, mais ainda, o pode impor sob a pena do fogo eterno"(50).

Esta prevenção não deixará de ser recuperada por algum anticlericalismo posterior, mormente o que denunciou o ultramontanismo e viu no poder temporal do Papa e no internacionalismo das ordens

(49) William Poppe, "Ao leitor", John Locke, ob. cit., p. 129.

(50) John Locke, ob. cit., p. 117. 
religiosas um obstáculo à consolidação do princípio da soberania popular ou nacional. Mas também mostra que, em última análise, o maior perigo dos "papistas" residia no facto de não respeitarem a distinção entre o político e o espiritual, afinal o fundamento último da tolerância.

Uma outra limitação que Locke lhe impôs diz respeito à rejeição dos ateus. No seu ideário, o convencimento da existência de Deus - mesmo que os seus atributos estivessem reduzidos, quase deisticamente, a um credo mínimo - e a crença na imortalidade da alma eram requisitos cruciais de sociabilidade. Consequentemente, "os que negam a existência de uma divindade não devem de maneira alguma tolerar-se. A palavra, o contrato e o juramento de um ateu não podem constituir algo de estável e de sagrado, pois são os vínculos da sociedade humana, a tal ponto que, suprimida a crença em Deus, tudo se desmorona"(51).

Estes dois intoleráveis - o catolicismo romano e o ateísmo - bastam para provar que, para ele, a pedra de toque do ideal de tolerância não é tanto a liberdade de consciência, mas mais a cimentação do contrato social, isto é, os laços morais necessários à vida política. Assim, o importante da questão centrava-se na articulação da defesa da liberdade do homem com a salvaguarda da paz do Estado. Perspectiva prática acerca dos elos entre tolerância, religião e paz civil que - conquanto com as características próprias a cada pensador - se encontrará em autores como Voltaire e na concepção rousseauniana de religião civil, baseada na crença na existência de Deus, na imortalidade da alma e no julgamento final, e, por isso, igualmente anatematizadora do ateísmo. Com efeito, para o autor de Émile, o reconhecimento da tolerância no campo das crenças individuais não era extensível às suas manifestações públicas. E, como o ateísmo não podia credibilizar a sacralidade do contrato social, todos os ateus deviam ser banidos da Cidade ${ }^{(52)}$.

Posição diferente havia sido teorizada por Pierre Bayle. Em 1682, em Pensées divers écrits à un docteur de Sorbonne, à l'occasion de la comète que parut ou mois de décembre de 1680 (título de 2. edição, de 1683)(53),

(51) Idem, ibidem, p. 118.

(52) Cf. Jean-Jacques Rousseau, Du Contrat social, Paris, Flammarion, 1992, pp. 166-168.

(53) Pierre Bayle, Pensées sur l'athéisme. Édition présentée, établie et annotée par Julie Boch, Paris, Éditions Desjonquère, 2004, pp. 41-118. 
sustentou que o critério de julgamento não estava no entendimento, nem em quaisquer motivações de ordem pragmática. Ao separar o problema da Verdade do da sinceridade das adesões, deu primazia à consciência - "a luz primitiva e universal que Deus difunde na alma de todos os homens" - e defendeu a existência de uma solução de continuidade entre a moral e a religião. Para escândalo de muitos, procurou mostrar que, se sociedades assentes em religiões minadas pelo vício e pelo crime geravam a imoralidade, "l'athéisme ne conduit pas nécessairement à la corruption des moeurs". É que, para o pensador francês, "peut avoir une idée d'honnêteté, sans croire qu'il y ait un Dieu"(54). Com esta valorização do ateísmo, ele pretendia dizer que a religião não somente era inútil para a concórdia civil, como lhe era nefasta, dado que transportava em si mesma factores de divisão. E - ao contrário do que defendiam autores como Locke e, mais tarde, Rousseau e Voltaire -, uma sociedade podia subsistir sem religião, pois a raiz da sua moralidade estava no âmago da consciência ${ }^{(55)}$.

A consequência maior do seu pensamento foi a defesa de uma moral racional, segundo a qual todo o homem, incluindo o ateu, está submetido a uma ordem de verdade independente da religião. É certo que invoca a luz de Deus no interior da consciência. Todavia, a suposição do ateu virtuoso secundariza a referência religiosa, em nome da convicção de que o espírito humano tem uma natureza própria, sem relações com os preceitos da fé e das obrigações sociais. Como ele mesmo afirmou: "Car puisque l'expérience nous montre que ceux qui croient un paradis et un enfer sont capables de commettre toute sorte de crimes, il est évident que l'inclination à mal faire ne vient pas de ce qu'on ignore l'existence de Dieu, et qu'elle n'est point corrigée par la connaissance que l'on acquiert d'un Dieu qui puni et qui récompense.... Il résulte encore de là que l'inclination à mal faire vient du fond de la nature humaine"(56). Em conclusão: para Bayle, o mal, ou melhor, a prática virtuosa (a piedade, a sobriedade, etc.) não decorre do facto de se conhecer ou não a existência de um Deus, mas de uma certa disposição do temperamento, fortificada pela educação, pelo interesse pessoal, pelo desejo de ser louvado, pelo

\footnotetext{
(54) Idem, ibidem, pp. 78, 93, 104.

(55) Cf. Julie Boch, "Preséntation", Pierre Bayle, ob. cit., p. 20.

(56) Pierre Bayle, ob. cit., pp. 87-88.
} 
instinto da razão, ou por motivos semelhantes, "qui se rencontrent dans un athée aussi bien que dans les autres hommes"(57).

Como se tem de reconhecer, transversal a estes momentos fortes do debate sobre o ideal de tolerância, encontra-se o seu paulatino deslocamento de uma problemática dominantemente teológica para uma outra, de cariz mais civil e secular. E esta, se não era antitética em relação à religião, não deixava de reivindicar a autonomia da consciência e a liberdade de pensamento. $\mathrm{O}$ que caminhou a par com a autonomização da moral e da exigência - tida como a premissa essencial da tolerância da separação entre o político e o espiritual, em ordem a conseguir-se garantir a liberdade religiosa, num contexto de secularização da sociedade e do Estado.

Em simultâneo, a herança da hermenêutica bíblica, com a aplicação do método histórico-filológico (em desenvolvimento desde o Humanismo), produziu efeitos secularizadores não só ao colocar as revelações do sagrado como objecto de conhecimento, mas também porque fomentou a crítica e a comparação, isto é, o culto da livre razão (como se nota em Espinosa) e o enquadramento histórico das questões. E, quando pensadores como Bayle desligam a justificação da tolerância e da sociabilidade de argumentos teológicos, situando-a no interior da consciência -incluindo a consciência errónea mas virtuosa -, insinuava-se uma separação entre a esfera religiosa e as necessidades de cimentação da ordem social, e, simultaneamente, postulava-se uma moral de cariz racional e secularizado, independente de legitimações transcendentes. Em suma: afirmava-se algo que o livre-pensamento posterior não deixará de reivindicar: a liberdade de consciência e de pensamento (Espinosa), expressões da construção da subjectividade, movimento que terá no eu puro transcendental de Kant e na sua actualização como razão teórica e razão prática - emancipada de qualquer tutela heterónoma e livremente afirmada na esfera pública - a sua teorização mais convincente. Por conseguinte, não admira que todas estas propostas tivessem confluído num imperativo de vocação emancipatória e paidética (Bildung).

Base deste processo de imanenticização (possibilitado pelos vários deísmos e panteísmos), foi a inversão antropocêntrica da moral, da sociedade e da política, tendo em vista encontrar um paradigma universal

(57) Idem, ibidem, p. 88. 
que, ao contrário de Deus, pudesse refazer o sonho da paz civil entre os indivíduos e os povos. Esse novo modelo passará a ser a natureza humana, vertente teorizada, como se sabe, pelas concepções contratualistas (Jean Bodin, Hobbes, Locke), depois integradas no jusracionalismo (Pufendorf, Thomasius e Heineccius), e concretizada, como projecto político democrático, em Jean Jacques Rousseau.

Assim sendo, não foi por acaso que os direitos naturais também passaram a ser utilizados como arma crítica e acusadora contra a intolerância, como se encontra já em Voltaire. Com efeito, no Tratado sobre a tolerância, este ideal perdeu a sua acepção passiva, sofredora e condescendente face a um mal, que se queria evitar, para se afirmar como uma virtude, simultaneamente moral e social, cujos efeitos seriam pacificadores $^{(58)}$. E a mesma justificação material não deixará de ser chamada a terreiro, como argumento emancipatório, em relação a tudo o que era apresentado como opressão, tendência que, nos seus efeitos políticos mais directos, irá desaguar nas Declarações dos Direitos do Homem, americanas e francesas ${ }^{(59)}$, fontes inspiradoras das respectivas revoluções. Por isso, quando, em 1789, a primeira Declaração Universal dos Direitos do Homem francesa consignou (art. $\left.{ }^{\circ} 10 .{ }^{\circ} \mathrm{e} 11 .{ }^{\circ}\right)$ : “Nul ne doit être inquiété pour ses opinions, même religieuses, pourvu que leur manifestation ne trouble pas l'ordre public établi par la loi", e "la libre communication des pensées et des opinions est un des droits les plus précieux de l'homme; tout citoyen peut donc parler, écrire, imprimer librement, sauf à répondre de l'abus de cette liberté dans les cas déterminés par loi", estava-se, simultaneamente, no fim de uma batalha e no meio de uma "guerra" que continua longe do seu desfecho.

Como se viu, as possibilidades de concretização destes direitos naturais exigia um clima de tolerância e este, como salientou Locke - na linha de outros (Tomás More, Milton, John Goodwin, Roger Williams) -, só podia ser criado quando as Igrejas e o Estado se posicionassem como sociedades exteriores e diferentes. Com isso, abriu-se a luta para se institucionalizar a separação - que irá ser objectivada de modos diversos -, secularizando o funcionamento e os objectivos perseguidos pelos homens enquanto

(58) Cf. Julie Saada-Gendron, ob. cit., p. 113.

(59) Cf. Marcel Gauchet, La Révolution des droits de l'homme, Paris, Éditions Gallimard, 1989. 
organizados como sociedade política, e privatizando o associativismo religioso, assim confinado à sua esfera própria: as peocupações sotereológicas e escatológicas dos indivíduos. E estas propostas não deixaram de provocar impactos, dado que apontavam para a secularização do estatuto das próprias Igrejas (reconhecidas como associações de crentes) e, concomitantemente, postulavam a imanência da raiz da soberania, invertendo e desconstruindo a lógica das teses jusdivinistas e secularizando a perspectiva ecuménica, de origem estóica e cristã.

No entanto, os novos pressupostos apontavam para soluções passíveis de gerar tensões. Se a verificação do facto de a religião poder provocar a anomia e a guerra aconselhava a tolerância, mediante a separação da esfera política da religiosa, ter-se-á de levar em conta que outros, a partir do mesmo diagnóstico, reivindicavam, para o Estado, uma função tutelar nesta matéria, não obstante o objectivo ser idêntico. Dir-se-ia que, com tais propostas, se reactualizava a tese de Marsílio de Pádua, para quem, em nome da paz, o Príncipe devia ter o controlo da religião no seu território, ou Bodin, que distinguiu o Estado e a religião, vendo esta - como o farão todos os regalistas - como um instrumento de poder nas mãos do Magistrado. Também para Espinosa e Hobbes - nas suas ópticas próprias -, o direito de regular as coisas sagradas e, consequentemente, a paz civil, devia pertencer ao Soberano ${ }^{(6)}$. Esta estadualização do problema não só era distinta da via mais liberal propugnada por Locke, como potenciava interpretações diversas acerca dos nexos entre as Igrejas e os Estados, como os que, conquanto no quadro da aconfessionalidade política, irão colocar o acento tónico, quase exclusivamente, na subjectividade.

\section{Secularização e Iluminismo}

Ficaram assinalados alguns efeitos da secularização. Mas, quais foram as suas causas, em particular as da sua aceleração nos séculos XVIII e XIX? Para alguns, $o$ antropocentrismo subjacente a todas estas transformações mais não é do que a resultante de apropriações (invertidas) e deslocamentos de potencialidades propiciadas pela própria religião, mas agora

${ }^{(60)}$ Cf. Julie Saada-Gendron, ob. cit., pp. 211-213. 
inscritas no autónomo e imanente horizonte da aventura humana. Percurso que, no plano teorético, remontaria à descoberta da dimensão horizontal da razão teórica e prática (intrínseca à natureza humana), com a doutrina do intelecto agente de S. Tomás e de Alberto Magno fundamento da separação da filosofia da teologia -, e que, passando por Descartes, abriu caminho ao transcendentalismo de Kant ${ }^{(61)}$. Reconhece-se, em síntese, que, com o filósofo alemão, se deram passos decisivos para se dessacralizar a natureza - indo-se mais longe do que no panteísmo de Giordano Bruno e de Espinosa -, se secularizar a razão teórica e prática, e para se entender Deus como um postulado racionalmente inverificável. No fundo, "salvar os fenómenos do conhecimento vulgar e científico, privilegiar o mundo da práxis e da esperança humana, declarar a impossibilidade do universo metafísico tradicional", foi o contributo da filosofia kantiana para a secularização ${ }^{(62)}$. Assim sendo, ganha sentido a caracterização que Kant fez da Aufklärung, ao considerá-la a passagem de uma atitude de heteronomia e de menoridade (Unmündigkeit), para a maioridade autónoma do homem, concretizada como liberdade de pensamento, praticada como razão pública.

Neste movimento, a capacidade humana para manipular a natureza - em curso desde o século XVII - alargou-se, condicionada pelas alterações sociais e económicas dos inícios da época moderna. E, com a afirmação do homem como ser racional e livre, apto para inteligir a legalidade imanente do cosmos, não só se secularizou a sociabilidade, como se criaram as bases epistemológicas e tecnológicas que servirão de instrumento à explosão científico-industrial do século $\mathrm{XIX}^{(63)}$. Este novo optimismo, por extensão da sua aplicabilidade aos fenómenos sociais, veio também a concretizar-se numa ideia terrena e irreversível de história, baseada no postulado segundo o qual o fieri do seu devir era ditado pela acção demiúrgica da humanidade. As teorizações acerca da natureza perfectível do ser humano, as concepções contratualistas, bem como as

(61) Miguel Baptista Pereira, art. cit., p. 488 ss.

(62) Idem, ibidem, p. 490.

(63) Cf. O. Chadwick, The Secularization of the European mind in the nineteenth century, Cambridge, Cambridge University Press, 1975; S. Bruce (ed.), Religion and modernization. Sociologists and historians debate on the secularization thesis, Oxford, Clarendon Press, 1992. 
fundamentações filosófico-progressivas do tempo histórico (Condorcet, Hegel), e, mais tarde, os esforços, mesmo ilusórios, para se cientificar a sociedade (Comte, Proudhon, Spencer, Marx), foram projectos que irradiaram da mesma centração imanentista e secular, perspectiva que fez da apoteose da razão, da ciência e do ideal emancipatório uma das características mais fortes da Modernidade.

Este modo de ver arrastou consigo a historicização (e a relativização) do entendimento do fenómeno religioso. Este foi encarado como uma das manifestações espirituais que objectivavam o sentido da história, mas que a razão poderia apreender. Anelo que as filosofias do devir humano, a antropologia filosófica e a sujeição da leitura dos textos sagrados ao método histórico-filológico materializarão num saber racional e crítico, ligando-o a acções apostadas em mudar a própria história.

A assunção da ideia de historicidade surge, deste modo, indissociável da secularização. No entanto, se, no caso francês, as Luzes entraram em choque directo com a ortodoxia das Igrejas - o que contribuiu para o desenvolvimento de uma via de cariz hostil, na qual a construção do mundo moderno exigia a emancipação da tutela religiosa, denunciada como um sentimento anacrónico, ou como fruto de ilusões supersticiosas -, a Aufklärung alemã, de uma maneira um pouco distinta, viu a Reforma como o momento inaugurador do movimento de aniquilação do antigo, isto é, como um trabalho de elaboração do novo, que ainda não teria terminado. Leitura que provocou esta tópica: o mundo moderno aparece menos como um mundo emancipado, mas mais como uma espécie de mundo cristão secularizado. Ora, estas diferenças sobre as explicações da génese da Modernidade acabarão por se reflectir no debate acerca dos condicionantes que terão conduzido à secularização.

Tais interpretações podem ser resumidas a duas posições-tipo, embora ambas consintam variáveis e compatibilizações ${ }^{(64)}$ : a que define a secularização como a perda do domínio da sociedade religiosa e, portanto, como uma consequência imediata da aceitação dos princípios em que radica uma certa ideia de Modernidade - a experiência do tempo moderno como uma novidade sem precedentes, e o convencimento de que os homens são capazes, cada vez mais, de "fazer" a história -, e a que

(64) Cf. Jean-Claude Monod, ob. cit., pp 29 e 46, nota 4. 
equaciona o fenómeno como uma transferência do conteúdo, dos esquemas e dos modelos elaborados no campo religioso, óptica que relativiza a novidade radical dos tempos modernos, assim reduzidos à condição de herdeiros, não obstante todas as suas ilusões de auto-fundação.

$\mathrm{Na}$ sua radicalidade, estas propostas são excessivamente dicotómicas, tanto mais que os três condicionantes que as podem explicar - contributo religioso, influência das revoluções racionalistas e científico-técnicas, e emergência da civilização urbana - reciprocamente se exigem ${ }^{(65)}$. É que a análise de algumas das principais teses (filosóficas, históricas, sociológicas, teológicas) que, nas últimas décadas do século $\mathrm{XX}$, foram avançadas para compreender e explicar o processo, assim como o confronto e a comparação com os seus presumíveis antecedentes, convidam a esta hipótese de trabalho: se parece claro que ele tem uma matriz greco-romana e, sobretudo, judaico-cristã, o certo é que esta filiação não pode significar a existência de uma mera continuidade, ou de uma simples inversão de planos, pois algo invertido mantém-se idêntico a si mesmo. Contudo, quando se está perante transformações desencadeadas pelo aparecimento de novas realidades, o novo pode integrar e transformar o antigo, embora este, se o potencia, não o possa prever, porque ele é sempre obra do futuro.

\section{Os multímodos condicionantes da secularização}

A reivindicação de uma matriz judaico-cristã para a secularização encontra-se bem representada na hermenêutica de pensadores como M. Buber e Karl Löwith, da chamada teologia liberal protestante (E. Troeltsch ${ }^{(66)}$, Gogarten ${ }^{(67)}$, Harvey $\left.\operatorname{Cox}^{(68)}\right)$, da teologia da secularização de origem católica (ex.: J. B. Metz) ${ }^{(69)}$, das teologias da esperança e da

(65) Sobre a problemática em apreço, veja-se D. Martin, A General theory of secularization, Basil, Blackwell Oxford, 1978.

(66) Cf. Peter Berger, La Religion dans la conscience moderne, Paris, Centurion, 1971, pp. 92, 136.

(67) Cf. F. Gogarten, Destin et espoir au monde moderne, Paris, Casterman, 1970.

(68) Cf. Harvey Cox, La Cité séculière, Paris, Casterman, 1968, p. 47 ss..

(69) Cf. J.B. Metz, Théologie du monde, Paris, Cerf, 1971. 
libertação, e em historiadores de mitos como Mircea Eliade ${ }^{(70)}$ e, à sua maneira, em sociólogos da religião como Peter Berger ${ }^{(71)}$. Mas também não se pode esquecer que, no interior das Igrejas, existem posições resistentes a este tipo de interpretações. Mais especificamente, alguns teólogos actuais, ligados ao Vaticano (o cardeal Ratzinger e a Congregação para a Doutrina da Fé), têm qualificado a secularização e a abertura ao mundo, defendida por João XXIII e Paulo VI, como um "fenómeno patológico do cristianismo"(72).

Não se irá pormenorizar este debate ${ }^{(73)}$, pois, para o propósito de agora, basta mencionar o núcleo forte dos argumentos que entendem a secularização como uma apropriação legítima do legado judaico-cristão. A criação ex nihilo, distinta das cosmogonias míticas e filosóficas clássicas (geração, processamento), provocou uma diferença essencial entre Deus e o mundo e, portanto, potencializou a dessacralização do cosmos. Este, criado por um acto único e irreversível, não se confunde com o Criador e passou a ter - ao contrário do que acontecia nas cosmogonias greco-romanas - uma onticidade espaço-temporal autónoma e não eterna. Por sua vez, a encarnação em Cristo humanizou a revelação divina, acto que situou o homem, feito à imagem e semelhança de Deus, perante a sua liberdade responsável, doando à história um sentido diacrónico que aponta, não para o regresso paradigmático a uma eternidade originária, mas para a consumação do destino humano no final dos tempos ${ }^{(74)}$. A historicização hierofânica e teofânica, num tempo sem regresso, convidava, assim, à aceitação de uma expectativa messiânica e escatológica, tendência que, por razões sócio-culturais várias (que o conceito de secularização exprime), se foram plasmando em sonhos de liberdade, gradualmente situados num horizonte terreno.

(70) Cf. Mircea Eliade, O Mito do eterno retorno, Lisboa, Ed. 70, 1981, p. 117 ss.

(71) Cf. Peter Berger, ob. cit., p. 186 ss..

(72) Uma crítica a esta leitura encontra-se em Juan José Tamayo, ob. cit., p. 38 e ss.

(73) Para um resumo das teses que valorizam a secularização na renovação da vivência cristã e o seu apelo ao compromisso com o mundo, leia-se Miguel Baptista Pereira, art. cit., p. 492 ss.

(74) Sobre os fundamentos filosóficos do cristianismo, veja-se, entre outros, Claude Tresmontant, La Métaphysique du christianisme et la naissance de la philosophie chrétienne..., Paris, Seuil, 1961. 
O protestantismo, com o relevo dado à predestinação e à graça, depreciou ainda mais o mundo secular, reforçando as condições para o autonomizar. E, como se sabe, não foi por acaso que Max Weber elegeu esta atitude - em particular na sua versão calvinista - como factor que condicionou a génese da racionalidade capitalista.

Em conclusão: mesmo reconhecendo-se que, em muitos casos, a secularização defrontou as religiões $-e$, sobretudo, as suas objectivações dogmáticas e institucionais -, enfatiza-se o facto de os textos sagrados fundadores conterem asserções que a sugerem e potenciam, em particular no que respeita à "historicização" da revelação do sagrado, à desdivinização do universo (que possibilitou a ciência moderna) e à "dessacralização da política", o que levou à demarcação entre o Império e o reino espiritual, modo concreto de "Dar a César o que é de César, a Deus o que é de Deus". E esta tese tem ainda a seu favor a circunstância de ter sido nas regiões cristianizadas (e não nas do Islão, nem nas de influência hindu ou budista) que se formaram as condições que conduzirão a experiências históricas nela inspiradas. Ter-se-á ainda de perguntar por que é que esta desenvolução não ocorreu sob a hegemonia do pensamento greco-romano (onde predominava uma concepção cíclica do tempo e o poder político estava sacralizado), nem nas demais civilizações, mormente nas de análogo cariz monoteísta.

Com efeito, o judaísmo, não só assenta na ideia de "povo eleito", como continua a perspectivar o futuro em termos de um messianismo que ainda espera a sua irrupção na história (daí que, na ausência do acontecimento central, a datação seja de tipo cosmogónico). É certo que, tal como no cristianismo, para o Islão, o profeta já chegou. Contudo, ao invés do que aconteceu com Cristo, Maomé não pretendeu fundar somente uma religião, pois o islamismo, desde os seus primórdios, teve sempre uma dimensão social, política e até militar, situação em parte explicável pelo contexto em que nasceu: a existência de um certo vazio político em relação aos impérios contemporâneos (o bizantino e o persa). O Profeta encarregou-se da organização social e política da comunidade dos seus fiéis, assegurando a sua vida, a sua defesa e a sua expansão. Este elo entre o político e o religioso manter-se-á no mundo muçulmano, levando a que, pelo menos a partir dos meados do século VII, o primeiro dominasse e utilizasse o segundo. Consequentemente, "la forme classique selon laquelle l'islam est à la fois, 'religion et gouvernement' (dîn wa dawla, en arabe), exprime sa nature réelle: 
elle rappelle qu'il ne sépare pas le religieux et le politique, même s'il sait les distinguer"(75).

O cristianismo promete a salvação num outro mundo, rejeitando, portanto, a confusão, típica da sociedade greco-romana, do religioso com o político - por isso, os romanos chamavam "ateus" aos novos cristãos -, e pregou, nos seus primórdios, a indiferença em relação aos governos. Como o seu reino nunca será deste mundo, e perante a força do Império, importava dar a César o que é de César e a Deus o que é de Deus, pelo que, como lembrou Santo Agostinho (século V), o cristão não podia confundir as duas Cidades, devendo obedecer - de acordo com Pedro e Paulo - às autoridades estabelecidas. No entanto, foi um facto que o Império Romano, ao tornar-se oficialmente cristão nos séculos III e IV (com Constantino e, sobretudo, com o édito de Teodósio, em 380), legitimou uma longa promiscuidade entre o religioso e o temporal, quer sob a forma cesaropapista, quer hierocrática. Mas esta situação nunca conduziu a qualquer fusão de planos - a Igreja manter-se-á, mesmo quando a subordinou, ou a ela se aliou, distinta e independente da organização política -, e nunca subsumirá o dualismo entre o espiritual e o século. Por isso, quando o Estado se desenvolveu e ganhou força para existir por si mesmo, teve de se subtrair à sua influência, considerando-a uma intrusa, incoerente com os seus próprios princípios, e obrigando-a a cingir-se à sua vocação espiritual primitiva ${ }^{(76)}$. Se esta, na essência da sua promessa, cultivava uma indiferença em relação ao poder temporal, a Modernidade relembrá-la-á, conquanto num outro contexto, lutando para que a sociedade e, sobretudo, o Estado fossem indiferentes e distintos do poder religioso.

Bem vistas as coisas, as razões apresentadas para explicar a secularização pela herança judaico-cristã podem ser resumidas a três: em primeiro lugar, a afirmação da transcendência de Deus implicou a consequente autonomização do mundo natural e político; em segundo lugar, Javé foi definido como um "Deus móvel", que intervém na história através de acções específicas, e a sua aliança com o povo eleito também é histórica, ficando assim rompida a lógica circular do cosmos e também insinuada a historicização - que a Encarnação reforçou - das relações do homem

(75) Maurice Barbier, "Laïcité: questions à propos d'une loi centenaire", Le Débat, n. ${ }^{\circ} 127$, novembre-décembre, 2003, p. 166.

(76) Idem, ibidem, pp. 165-166. 
com Deus, o que abriu um campo de possibilidades para a sua assunção como ser livre e responsável no tempo; em terceiro lugar, a normatividade moisaica e a esperança escatológica no Juízo Final definiram o novo Deus como um Deus ético, premissas que incitaram as consciências cristianizadas a racionalizarem os ditames da moral e a desenharem horizontes de expectativas que serão projectados na história.

Tais pressupostos bíblicos e evangélicos só a pouco e pouco foram explicitados na riqueza das suas consequências. O peso da mentalidade mítica - sobretudo ao nível dos comportamentos populares - e a mediação neoplatónica e aristotélica na interpretração do Livro bloquearam a sua hermenêutica, não sendo de estranhar a insensibilidade filosófica e teológica perante a novidade judaica e cristológica. $E$, ao invés do que defendeu Blumenberg(77), a mundanização precoce da Igreja como instituição não impediu que a escatologia cristã fosse abrindo as mentes para a ideia de futuro, em particular através da sua vertente apocalíptica e messiânica que Roma condenará como heresia. Neste contexto, compreende-se que estas interpretações se tenham desenvolvido, em boa parte, numa relação conflituosa com as leituras dogmáticas e eclesiais do Novo e do Velho Testamento.

Por outro lado, as confissões protestantes objectivarão, ainda mais, as sementes secularizadoras do núcleo cristão, ao fazerem refluir a presença do sagrado na realidade e ao instalarem uma distância intransponível entre Deus, radicalmente transcendente, e o homem, ente predestinado e entregue a si mesmo num mundo dessacralizado. Com tudo isso, empolou-se a mediação subjectiva da própria vivência religiosa e provocou-se o despovoamento do céu, espaço infinito cada vez mais descrito na linguagem matemática de astrónomos e cientistas.

A releitura do legado judaico-cristão é particularmente visível na ideia de tempo histórico que substituiu as visões cíclicas e providencialistas. E, quando estas últimas entraram em crise, afirmou-se a crença na autonomia do homem e na sua capacidade criadora, polarizada pela aspiração de conquistar, na terra, a felicidade plena, atitude que caminhou para a sua consequência maior: o anúncio da "morte de Deus" (Nietzsche). Sabe-se como este desejo sofreu uma mediação racional e se encorporou nas filosofias do progresso e da perfectibilidade humana, como o

(77) Cf. H. Blumenberg, ob. cit., pp. 11-136. 
demonstrou Karl Löwith, principalmente em Meaning in history $(1940)^{(78)}$. E foi sobretudo devido à influência desta obra que a definição das filosofias modernas da história como formas secularizadas da história da salvação quase se transformou num dogma (Blumenberg). No entanto, convém lembrar que Löwith, ao salientar esta tese, não escamoteou o facto de o efeito - o historicismo - ter dado origem a uma realidade (ideológica) nova em relação à sua fonte.

Em síntese: após interpretações sobre o tempo como as de Karl Löwith, Oscar Cullmann (Christus und die Zeit, 1946) e Rudolph Bultmann (Offenbarung und Heilsgeschechen, 1941), vários são os que aceitam que as novas filosofias da história, sobretudo a partir de Voltaire e de Turgot, operaram uma nem sempre assumida racionalização e imanenticização do velho providencialismo (Bossuet), tendo em vista a legitimação de uma ideia de esperança (alicerçada na crença na perfectibilidade e no progresso indefinido), na qual o futuro, distinto do passado, passou a ser experienciado como um ideal optimista de consumação, isto é, como uma mundanização e historicização da escatologia cristã.

Nesta mesma linha se situam os que entroncam as ideias utópicas nos sonhos milenaristas semeados por leituras (heterodoxas) da Bíblia. Em algumas revoltas sociais - como as dos camponeses alemães dos séculos XVI e XVIII ${ }^{(79)}$, ou as dos operários da fase inicial da industrialização que ainda não teriam ascendido à ideologicização ("primitivos rebeldes")(18) -irromperam, com efervescência, esperanças messiânicas e milenaristas de raiz judaico-cristã, apropriadas como armas de contestação da ordem social estabelecida. Ernst Bloch estudou o significado social da revolta de Thomas Müntzer ${ }^{(81)}$, depois das sugestões de Max Weber;

(78) Cf. Jeffrey Andrew Barash, "Karl Löwith et la politique de la sécularisation", Politique de l'histoire. L'historicisme comme promesse et comme mythe, Paris, PUF, 2004, pp. 167-186.

(79) Cf. Ernst Bloch, Thomas Münzer, theólogien de la révolution, Paris, UGE, 1975. A $1^{\text {a }}$ edição alemã data de 1921.

(80) Para o estudo das manifestações messiânicas e milenaristas no operariado, na fase de arranque da industrialização, veja-se, sobretudo, a obra de E. J. Hobsbawm, Rebeldes primitivos. Estudos de formas arcaicas de movimentos sociais nos séculos XIX e XX, $2^{\mathrm{a}}$ ed., Rio de Janeiro, Zahar, 1978, p. 64 ss.

(81) Cf. Laënnec Husbon, Ernst Bloch. Utopie et espérance, Paris, Cerf, 1974, pp. 41-51. 
e as análises de Henri Desroche ${ }^{(82)}$ assinalaram os parentescos existentes entre a cosmogonia e a escatologia judaico-cristãs e as representações prospectivas da história.

Perante o que ficou escrito, pode dizer-se que as novas doutrinas sociais de cariz utópico não são estranhas às ideias de finalidade e de inteligibilidade do devir - o providencialismo secularizado transformou-se num teleologismo imanente-, esperança inoculada pela interiorização da visão bíblica do tempo. Aliás, os reformadores sociais dos meados do século XIX, apesar de anticlericais, explicitaram essa filiação, e mesmo alguns dos que prolongaram, em sentido materialista, a crítica antropológica à essência das religiões, inaugurada por Feuerbach, não lhe foram inteiramente estranhos, como o mostra, em relação ao marxismo, a filosofia da esperança de Ernst Bloch ${ }^{(83)}$. Nesta perspectiva, o humanismo e o historicismo evolucionista - valores que se tornarão dominantes na Modernidade - são um dos pontos de chegada do longo processo de secularização, e o desejo utópico-enquanto aspiração à cidade de Deus na terra - funcionou como um apelo praxístico suscitado pelo compromisso demiúrgico do homem com a sua historicidade ${ }^{(84)}$. Foi à luz desta "antropologicização do céu" que Bloch pôde concluir, na sua obra Atheismus im Christentum (1968), que "só um ateu [pode] ser um bom cristão". (Pierre Bayle, no seu contexto próprio, já havia defendido algo de parecido).

A definição do homem como ser autónomo (e não heterónomo, como na concepção religiosa) foi concomitante com a progressão de uma mundividência em que o universo (e a ordem histórica e política) emerge não só cindido de Deus (deísmo, agnosticismo), mas também do próprio homem, posição que o dualismo cartesiano (res extensa e res cogitans) prenuncia. Este vazio ontológico entre o sujeito e a realidade (que, no século XVIII, Vico procurou superar) e a consequente matematização da natureza devem ser vistos como requisitos necessários para o cumprimento do novo ideal de conhecimento: a produção de um saber científico que, como escrevia Francis Bacon, almejava matematizar as explicações dos fenómenos e alcançar a previsão, a fim de aumentar o poder humano sobre as coisas e sobre os homens (saber para prever $e$

(82) Cf. Henri Desroche, Sociologie de l'espérance, Paris, Calman-Lévy, 1973.

(83) Cf. Ernst Bloch, Le Principe Espérance, 3 vols., Paris, Gallimard, 1976-1982.

(84) Cf. Pierre Fuster, "Utopie et marxisme selon E. Bloch", Archives de Sociologie des Religions, $\mathrm{n}^{\circ} 21$, janvier-juin, 1966, pp. 13-21. 
prever para poder), divisa que, no século XIX, A. Comte repetirá, e que, de certo modo, sintetizará os objectivos gnosiológicos da Modernidade.

A crescente manipulação da natureza, em curso desde o século XVII, aumentou nos seguintes, pois, com a definição do homem como ser racional e livre, crente na inteligibilidade da auto-suficiência do universo, ficaram reunidas as condições epistemológicas que servirão de base à revolução científico-industrial da época contemporânea. E este optimismo alargou-se aos fenómenos históricos e sociais. Consequentemente, se a secularização é incompreensível sem a racionalização, ela também é tributária do crescimento da historicização e sociologização das explicações do mundo e da vida que ganharam força no século XIX. Esta extensão saldou-se no equacionamento da sociedade como uma realidade auto-regulada e atravessada por uma diacronia teleológica e irreversível que poderia ser controlada e acelerada mediante a acção do próprio homem. As teorizações sobre a natural perfectibilidade humana (Condorcet), as concepções filosóficas sobre o tempo histórico progressivo (Kant, Hegel) e, mais tarde, os esforços para as cientificar (Comte, Proudhon, Spencer, Marx e subsequentes discípulos) foram irrigados pela mesma água (optimista e secular) que alimentava os rios dos vários ideais emancipatórios da Modernidade.

Assim sendo, a historicização do entendimento do fenómeno religioso - tenha ela sido feita sob o impacto (de "direita" ou de "esquerda") da filosofia hegeliana do Espírito (Feuerbach, David Strauss, Bruno Bauer), ou realizada à luz das novas sociologias da religião, ou da aplicação do método histórico-filológico à análise dos próprios textos evangélicos propulsionou a secularização. Ao transformar os fenómenos religiosos em objecto de conhecimento, relativizou o seu valor e reforçou o convencimento de que a humanidade estaria a entrar na definitiva era da positividade, prognosticando a "morte de Deus", ou a insolúvel coexistência da Sua incognoscibilidade com os resultados da ciência (Herbert Spencer). Dir-se-ia que, com tais teses, se anunciava uma teoria sociológica da secularização, perspectiva que Durkheim e, sobretudo, Max Weber, saberão desenvolver de um modo inovador.

Para o grande pensador alemão, a sociedade moderna, entre as várias formas de racionalização (teórica, substantiva, prática e formal) que cultivou, deu particular atenção a esta última, definida como intenção de se alcançar certos fins pragmáticos, embora, ao contrário da razão prática, recorresse a regras abstractas. Este modo de pensar desenvolveu-se, com maior 
ênfase, nas sociedades científico-industriais e manifestou-se nas esferas da economia, do direito e da organização burocrática das relações sociais ${ }^{(85)}$.

Explicitando a tese de Weber, pode sustentar-se que as forças secularizantes, potencialmente inscritas no cristianismo, se expandiram de um modo mais acentuado com a ascensão capitalista. O enlace entre secularização e a industrialização resultou do facto de esta necessitar de saberes-fazeres científicos e técnicos, isto é, de um elevado grau de racionalização, não somente no campo das "infraestruturas", mas também ao nível das consciências. E o novo espírito racional, inerente à nova ordem económico-social, alastrou a outras instituições e, particularmente, ao Estado. Obrigado a preocupar-se, cada vez mais, com as implicações políticas e jurídicas da produção económica, ele teve de adaptar a sua própria estrutura àquela finalidade, o que conduziu ao estabelecimento de burocracias altamente racionalizadas e, em termos ideológicos, ditou a entrada em acção de novas formas de legitimação extra-religiosas.

Comummente, o conceito weberiano de secularização (e de racionalização) aparece articulado com outros, a saber: o desencantamento do mundo (Entzauberung der Welt) ou a desmagificação do mundo. Porém, estes, na sua aplicação histórica, nem sempre se requerem. A sua génese estaria na própria profecia veterotestamentária e no abandono da salvação sacramental-eclesisástica, trazido pelo protestantismo. Mas a depreciação sacral do mundo, a cientificação do universo e a historicização do devir ajudaram a cortar o cordão umbilical do homem com o cosmos e a interiorizar as obrigações éticas fomentadas pela religião judaico-cristã (a emergência de um Deus ético), assim como a autonomizar os efeitos terrenos da sua acção (que a ética protestante impulsionou) e, consequentemente, a acelerar o desencantamento, atitude que o crescimento da civilização urbana tornou ainda mais evidente.

De facto, foi a partir dos efeitos civilizacionais da cidade e da técnica que o teólogo americano Harvey Cox (tanto em $A$ Cidade secular, como em Regresso de Deus), inspirando-se em Max Weber, Gogarten e Bonhoeffer, explicitou o consabido laço existente entre secularização e urbanização. Mais concretamente, por urbanização pretendeu designar o afundamento da religião tradicional, a delibitação do império das concepções religiosas sobre o mundo e a ruína dos mitos sobrenaturais e de todos os símbolos

(85) Cf. Max Weber, Le Savant et le politique, Paris, UEG, 1963, pp. 69-76. 
tradicionais. Para precisar estes efeitos, recorreu aos conceitos que Tönnies tematizou no seu livro Gemeinschaft und Gesellschaft. Grundbegriffe der reinen Soziologie (1887), para sublinhar que a secularização facilitou o trânsito da forma de organização em comunidade para a de sociedade, onde os membros já não se vinculam em termos de parentesco e de obrigação, mas de vontade e de contrato. Esta base conceptual serviu-lhe para qualificar a urbanização como uma estrutura de vida, na qual a diversidade e a desintegração da tradição alcançaram o seu cume, assim como a despersonalização resultante da multiplicidade das novas relações funcionais. No entanto, este percurso também deu origem a uma espécie de anonimato, criando formas de vida potencialmente mais tolerantes, porque a vontade $\mathrm{e} o$ contrato substituíram as sanções morais costumeiras e as relações e vínculos de longa duração, típicas da vida em comunidade.

Conclui-se que existe um evidente cruzamento entre todos os factores que condicionaram a gradual emergência, nas regiões cristianizadas, de uma civilização secularizada. E, se se fizer uma leitura a partir das expressões contemporâneas do fenómeno - reduzindo-as, porém, a ideias-tipo -, verifica-se que as sociedades actuais do Ocidente a acentuaram ainda mais, ao sobrevalorizarem valores como a autonomia, a subjectivação, a privacidade, e ao generalizarem o pluralismo religioso, atitudes que, com a cientificação, socialização e historicização, racionalizaram e, sobretudo, mundanizaram e pluralizaram as visões do mundo e da $v^{v i d a}{ }^{(86)}$. Mais especificamente, este processo está em consonância com $o$ da perda de controlo do religioso sobre as relações sociais e, no terreno cultual, com o declínio da atraç̧ão dos seus ritos e símbolos, pelo menos nas suas manifestações mais institucionais ${ }^{(87)}$.

Por tudo isso, em termos sintéticos, pode defender-se que a secularização fez diminuir o significado da religião e, principalmente, das suas instituições e dos seus símbolos na vida dos povos ocidentais. $O$ que gerou a recessão das vocações e das práticas religiosas, e o enfraquecimento do controlo clerical sobre a vida privada e social dos crentes, consequências lógicas de um evidente refluxo do eclesial (e do sagrado) como quadro de referência axiológica e escatológica, a favor da afirmação

(86) Cf. Olivier Tschannen, Les Théories de la sécularisation, Genève-Paris, Librairie Droz, 1992.

(87) Cf. Marcel Gauchet, Le Désenchantement du monde. Histoire politique de la religion, Paris, Gallimard, 1985. 
da autonomia do sujeito e dos seus direitos naturais, ou melhor, da sua liberdade de consciência e de acção, assim como do peso de expectativas com uma orientação dominantemente terrena.

Todavia, recentemente, parece assistir-se, nas regiões mais secularizadas, ao "regresso" do sagrado, fenómeno que estará a pôr em causa as teses filosóficas que, desde o século XIX, prognosticaram a "morte de Deus" às mãos do homem racional e dos imperativos da história ${ }^{(88)}$. Com efeito, basta pensar no que se ali passa, incluindo as áreas influenciadas por outras religiões, para se relativizar previsões como as que anteviam "o eclipse do sagrado na sociedade industrial" (S. S. Acquaviva), ou a sua inevitável reclusão na esfera privada (Th. Luckmann). O religioso parece apostado em recuperar, em muitos casos de um modo beligerante, o espaço público, de onde foi "expulso" nos séculos imediatamente anteriores, seja na sua versão católica oficial, seja na sua modalidade mais crítica (cristianismo "progressista" do Primeiro Mundo, cristianismo libertador do Terceiro Mundo). E o que ocorre no islamismo será a versão mais radical desta onda aparentemente "regressiva".

Ora, a compreensão desta espécie de "vingança" do sagrado não pode ser feita a partir de pressupostos análogos (ainda que invertidos) àqueles que foram usados para prever a sua extinção, isto é, ela não pode ser justificada em termos histórico-evolutivos, agora colocados num terreno contrário, mas não diferente. Defende-se, assim, que se terá de saber o que, do novo, se mantém naquilo que, aparentemente, constitui um "retorno". Logo, para além dos efeitos provocados pelo processo de secularização no interior das próprias Igrejas - por exemplo: a aceitação, finalmente, dos direitos fundamentais do homem e da liberdade religiosa -, dever-se-á também indagar acerca do modo como, nas sociedades massificadas e anónimas actuais, se experiencia o sagrado, pois sabe-se que, como alerta o teólogo Juan José Tamayo, "hoy la experiencia religiosa não se canaliza sólo ni principalmente por vía institucional, ni siquiera a través de la adscripción a una religión. Mas aún, coexisten las manifestaciones de lo sagrado y la indiferencia ante el mensage y ante las formas estáticas de la mayoría de las religiones"(89). E são estas diferenças que levam alguns autores a falar de uma "segunda secularização", ou numa

(88) Sobre este tema e os vários "paradigmas" da secularização, leia-se Steve Bruce, God is dead. Secularization in the West, Oxford, Blackwell Publishers, 2002.

(89) Cf. Juan José Tamayo, ob. cit., p. 51. 
radicalização do longo processo da primeira, cujas consequências maiores se objectivam em múltiplas formas de viver a fé, mas centradas, sobretudo, na valorização da consciência individual. Por isso, alguns outros preferem qualificar o fenómeno com uma "desinstitucionalização" do religioso devido ao divórcio ou ruptura entre a mediação pessoal da religião e as normas eclesiais ${ }^{(90)}$.

Mais concretamente, estudos recentes acerca das relações entre as vivências religiosas e as respectivas Igrejas, feitos em vários países europeus, têm revelado, nas suas diferenças, algumas características comuns, a saber: a individualização (o culto do it yourself em matéria religiosa); a subjectivação (a valorização da experiência), a esteticização (o gosto da encenação), a emotividade (a procura de uma religião "quente", oposta às religiões "frias" e formais institucionalizadas); o indiferentismo (atenuação eufemística das diferenças entre as religiões e as expectativas pragmáticas); e a eticização (efeito do ecumenismo dos direitos do homem) ${ }^{(91)}$. Por conseguinte, pode afirmar-se que, se as incidências mais visíveis da secularização foram de ordem política e social, o certo é que elas se repercutiram, mais radicalmente, no domínio da cultura, atravessando as próprias objectivações da fé. Daí que François-Andrè Isambert tenha razão, ao precisar que, sob o termo secularização, não se visa designar um recuo, tão problemático como global, do religioso, "mais plus particulièrement la mise en question des pouvoirs spirituels, tant sur le plan intellectuel que culturel et institutionnel"(92).

Em conclusão: durante os últimos séculos, a secularização concretizou-se como um movimento simultaneamente desestruturante e estruturante da sociedade, pois, se ela provocou mudanças no relacionamento entre as Igrejas, o (novo) Estado e a sociedade, também deu origem a profundas transformações culturais. E estas expressaram-se em ideias, valores e expectativas que provocaram alterações na maneira como os indivíduos e os grupos passaram a interpretar o sentido da história, a justificar as suas acções no mundo, a fundamentar os seus projectos e as

(90) Cf. Antonio Vasquez Fernández, ob. cit., pp. 212-213.

(91) Cf. Jean-Paul Willaime, "Unification européenne et religions", Jean Baudouin et Philoppe Portier, La Laicité, une valeur d'aujourd'hui? Contestations et renégociations du modèle français, Rennes, PUR, 2001, p. 142.

(92) François-Andrè Isambert, "Le sociologue, le prête et le fidèle", Henri Mendras et al., La Sagesse et le désordre. France 1980, Paris, Gallimard, 1980, p. 24. 
suas estratégias, a povoar os seus imaginários e a justificar a sua vocação sociabilitária ${ }^{(93)}$. Efeitos que fizeram aumentar não só a desadequação das Igrejas ao século - sinal de um maior distanciamento da sociedade em relação à religião, consequência da progressiva autonomização do público e do privado, do íntimo e do comunitário, do subjectivo e do institucional -, mas também ampliaram e tornaram mais complexas e plurais as representações do mundo e da vida, secularizando a conferição de sentido (da história e da própria vida individual) e outorgando um papel decisivo à acção do homem no mundo ${ }^{(94)}$.

O próprio campo religioso também não ficou incólume a esta sobredeterminação. É que, como sublinha a contemporânea "teologia do pluralismo religioso", as próprias lições da história das religiões mostram a existência de uma pluralidade de manifestações do divino, da transcendência e do mistério, assim como de mediadores, profetas, intérpretes e testemunhas, ao mesmo tempo que se reconhece a presença de um significado salvífico em todas elas. Consequentemente, para muitos, uma religião só será autenticamente tolerante se aceitar o carácter "dialógico de la v(V)erdad con minúscula e con mayuscula"(95).

\section{II \\ De "laós" a laicidade}

Diz-se que a polémica sobre a secularização e a laicidade está viciada, porque esta terminologia, sendo filha da linguagem fixada no interior da religião judaico-cristã, surge condicionada por este contexto. Afirmar isto significa não levar em conta a origem pré-cristã dos seus radicais e não perceber que foram os seus derivados greco-latinos que recobriram a novidade religiosa, e não o contrário. Amiúde, também se encontra o uso de ambos os termos como se de sinónimos se tratasse, isto é, como se toda a secularização fosse uma laicidade. Procurar-se-á mostrar a pertinência desta hipótese, aplicável, em particular, aos países católicos: se toda a laicidade é uma secularização, nem toda a secularização é uma

(93) Cf. Laurent Laot, Catholicisme, politique, laïcité, Paris, Éditions Oeuvrière, 1990, p. 23.

(94) Cf. Fernando Ferrarotti, ob. cit., p. 120.

(95) Juan José Tamayo, ob. cit., p. 19. 
laicidade e, sobretudo, um laicismo. Por conseguinte, precise-se um pouco melhor estes últimos vocábulos.

\section{O povo como laós}

É certo que o estatuto de pessoa laica se foi autonomizando em equivalência com o de secular e em clara demarcação com o de clérigo. Porém, é necessário esclarecer não só toda a semântica que a palavra saeculum envolveu, mas também precisar melhor o itinerário de laós, a fim de se inteligir por que é que, a partir de uma dada conjuntura e experiência históricas, termos como laicidade e laicismo virão a ser utilizados, não no interior de uma comunidade de crentes organizada como Igreja, mas contra esta. Remontar às suas origens e entender as suas posteriores reactualizações-nomeadamente as ditadas pelos caminhos polémicos da secularização - será o objectivo das páginas que se seguem.

Em grego, laós (do radical indo-europeu lei) teve uma origem militar, contexto em que exprimiria a relação pessoal de um grupo de homens com um chefe por consentimento mútuo, denotando, portanto, um tipo de organização característico das antigas sociedades guerreiras. Assim, qualificaria o povo enquanto povo armado e dirigido por um chefe, pelo que não se aplicava às crianças e aos velhos; seria, em suma, uma comunidade guerreira. Cedo, porém, ganhou o significado de "'povo' ou 'gente do povo'. Neste caso, trata-se de indivíduos (em geral homens) não qualificados, que se distinguem pela actividade ou circunstância ocasional que os agrupa"(96) Por isso, esta acepção não se confundia com a de dêmos, conceito territorial e político que designava, como ensinou Émile Benveniste, tanto uma porção de terra, como o povo que aí vivia, unido somente por uma comum condição social (e não por um elo de parentesco, ou por uma pertença de carácter político).

Laós distinguia-se, igualmente, de óchlos, que referenciava "gente", "massa", "plebe", e de éthnos, palavra que não se aplicava somente aos homens, mas também a animais, abelhas (contextos em que dêmos nunca surge $)^{(977}$. Quer isto dizer que éthnos tinha o sentido de grupo de humanos

(96) Telmo Verdelho, art. cit., p. 26.

(97) Émile Benveniste, Le Vocabulaire des institutions indo-européennes, vol. 2, Paris, Les Éditions de Minuit, 1969, pp. 90-98. Cf. Telmo Verdelho, art. cit., pp. 25-26. 
estritamente vinculados entre si por uma história e por um espaço vital comum, conotando, portanto, características culturais ou civilizacionais.

Por sua vez, o termo pólis era usado para exprimir uma realidade de forte acentuação política, ao denotar a comunidade que, organizadamente, vivia junta, mas sob uma constituição civil e jurídica, isto é, como cidade-estado.

Quanto a laós, é um facto que a palavra veio a ultrapassar a sua primitiva semântica, que Homero registou, passando a querer dizer que, antes de ser dêmos e de se formar como pólis, o "povo" seria laós, base substancial daquelas duas outras expressões ${ }^{(98)}$. Pelo que não será errado definir o "povo", enquanto laós, como os seres humanos que vivem em conjunto, num determinado momento, "qu'elle que soient leurs origines, leurs croyances, leurs aspirations"(99).

As versões gregas do Antigo e o Novo Testamento registam laós e, quando o fazem, o seu sentido é um pouco indefinido, embora, na maior parte dos casos, a palavra sirva para qualificar o antigo e o novo povo de Deus, respectivamente. Mas os pagãos são chamados, de um modo genérico, éthnos ou éthné (no plural). E não deixa de ser sintomático que o conceito que melhor caracteriza a autocompreensão do grego como "homem político", a pólis, tenha um lugar muito secundário nos textos bíblicos.

Em suma: para assinalarem a aliança entre Israel e Javé, aos tradutores gregos do Antigo Testamento pareceu-lhes mais adequado fazer corresponder a palavra hebraica am a laós, termo que qualifica Israel como o povo eleito de Deus, frequentemente em contraste com a palavra hebraica goy, usada para denominar os pagãos (éthné). Portanto, o que na maior parte das suas significações transforma o povo judeu em laós é a eleição e a graça de Deus, não as suas características étnicas, naturais ou históricas.

Laós aparece 141 vezes no Novo Testamento. E se, numa delas, é sinónimo de óchlos, na maior parte dos casos, refere-se ao povo judaico. Todavia, em muitos outros passos, verifica-se que este título honorífico - ser o laós de Deus - foi transferido para os fiéis da Igreja cristã. Entre os vários éthné, Deus escolheu um laós para ele. De facto, no grego tardio,

(98) Cf. Henri Pena-Ruiz, La Laïcité, Paris, Flammarion, 1998, e Dieu et Marianne, Paris, PUF, 1998.

(99) Jean Michel Ducomte, La Laïcité, Toulouse, Éditions Milan, 2001, p. 20. 
laós deu origem a laikós, de onde nasceu a expressão latina laicus e, em português, leigo e laico ${ }^{(100)}$.

Com a consolidação do dualismo entre a vida espiritual e a temporal, ou melhor, com a divisão, no interior do cristianismo, entre clérigos e seculares, a acepção bíblica de povo de Deus começará a ser usada para demarcar esta nova hierarquização. Segundo alguns autores, laikós terá aparecido, pela primeira vez, em 96 d.c., numa carta do papa Clemente, para qualificar um fiel, em oposição a um diácono ou a um padre (os iniciados e detentores do saber). Com o tempo, expressões como "irmão leigo" significavam "irmão servidor", a quem era confiado os trabalhos manuais nos mosteiros, durante a Idade Média ${ }^{(101)}$. Consolidou-se, assim, a velha dicotomia entre os detentores do poder espiritual e o mundo, num processo em que, no interior da Igreja, leigo tendeu a ser sinónimo de secular. Mas, em consequência da depreciação do trabalho manual (herdada da tradição grega), aquele vocábulo também foi recebendo conotações pejorativas.

$\mathrm{Na}$ verdade, a relação antinómica de leigo com clero ou padre está desde cedo comprovada. Depois do século XII, o termo foi igualmente utilizado tanto no sentido de "secular" como no de "ignorante"(102), embora, até ao século XIII, a palavra laico fosse rara e o seu uso não ultrapassasse uma restrita esfera de eruditos. No século $X V$, ela tornar-se-á mais conhecida, em particular quando aplicada aos membros de uma sociedade religiosa que não eram padres ou clérigos, não obstante todos serem considerados elementos constituintes do povo de Deus. Simultaneamente, popularizou-se um significado mais depreciativo: leigo é o ignorante, contrastando com a sabedoria do clérigo e, mais tarde, por secularização, do "homem de letras".

Segundo o Oxford English Dictionary, a palavra inglesa laic teve o seu primeiro registo em 1562, e laity (laicado) encontra-se a partir de 1540. E, em francês, lai/laïe recebeu, em 1606, esta definição dicionarizada:

${ }^{(100)}$ Nesta síntese, seguimos o artigo "Pueblo", em Lothar Coenem, Erich Beyreuther e Hans Bietenhard, ob. cit., vol. 3, pp. 437-448; e Telmo Verdelho, art. cit., p. 28 ss.

(101) Cf. Yves Congar, Enciclopédie de la foi, Paris, La Cerf, 1967.

${ }^{(102)}$ Cf. Pierre Fiala, "Les termes de la laïcité. Différenciation morphologique et conflits semantiques", Mots, n. ${ }^{\circ} 27$, Juin, 1991, p. 46. 
"aquele que não tem nenhum grau de clericatura" (Nicot), e o célebre dicionário da Academia (ed. de 1694) inseriu os dois artigos seguintes: "LAIQUE. adj. de tout genre. Séculier. Il est opposé à Clerc et Ecclésiastique. Une personne laïue, un officier laïque, de condition laïqu; Il est souvent substantif. Un laïque, Les Ecclésiastiques et les laïques"; "LAY, AYE. adj. Laïque. Un Conseiller lay traduire un Ecclésiastique en cour laye. Patron lay. On appelle, Un frère lay, un Moyne lay. Les frères servants qui ne sont point destinés aux Ordres sacrés: et de mesme on appelle Soeurs layes Les Religieuses qui ne sont point du choeur.... Il est aussi quelquefois substantif"(103).

Em português, muitos destes sentidos encontram-se no célebre Vocabulário de Rafael Bluteau (1716). Assim, registando a palavra "laical", este escreveu: "cousa de leigo ou de Irmão Leigo em ordem religiosa". Ao mesmo tempo, definia "leigo" como um adjectivo que tinha por origem o "grego laós, que vale o mesmo que povo", e esclarecia: "chama a Escritura pão leigo ao pão não sagrado. Chama-se leigos a todos os que não são clérigos, nem ordenados. Leigo vale o mesmo que não clérigo".

O direito canónico consagrou a distinção: leigo referia-se ao crente a quem faltava toda a participação no poder da Igreja, fosse ele de jurisdição, fosse de ordenação. E esta destrinça fez doutrina, pelo menos até ao Concilio Vaticano II, que dedicou todo um capítulo ao assunto. Excluindo os membros comprometidos com uma ordem sagrada e com um estado religioso, leigos são todos os fiéis reconhecidos pela Igreja e em cujo governo eles devem participar. Nesta (nova) perspectiva, leigo já não pode ser confundido com secular, porque os crentes que fazem profissão de fé num instituto religioso, sejam eles clérigos ou meros fiéis, cessam de ser seculares ${ }^{(104)}$.

De tudo isto se concluiu que a expressão laico transitou da tradição grega para as traduções bíblicas e destas para significações que o direito canónico encorporará. Seja como for, o impacto da vertente jurídico-política e, sobretudo, histórico-filosófica da secularização irá alargar o seu campo semântico, veiculando intenções que já não serão de mera demarcação, mas de aguerrida crítica a clérigo e à própria Igreja.

(103) In Idem, ibidem, pp. 43-44.

(104) Cf. S. Bencheik, Marianne et le prophète. L'Islam dans la France laïque, Paris, Grasset, 1998, pp. 23-25. 


\section{As palavras como armas}

A génese de novos termos a partir dos radicais que deram origem a leigo e a laico indicia os percursos diferentes que ambos irão trilhar. É que, se o radical leig deu leigo, dele também medraram outros vocábulos, que vieram a ser usados num clima mais erudito, porque, segundo os especialistas, eles seriam morfologicamente mais aptos "para a criação de derivados cultos, formados com os sufixos do amplo mundo da abstracção ideológica (laical; laicalismo ou laicismo; laicização; laicizar)", tudo expressões que "puderam ser adoptadas pelo discurso positivista para significar em primeiro lugar a oposição a clerical e a clericalismo e depois, de modo mais geral, a oposição a todo o universo de referência confessional ou simplesmente religiosa"(105).

Este tipo de desenvolvimento ocorrerá com mais força nas áreas político-culturais em que o Iluminismo e as experiências revolucionárias modernas colidiram com as Igrejas que detinham poderes (económicos, políticos, culturais) que obstaculavam a modernização. Exemplarmente, esse será o caso da França e, em maior ou menor grau, o dos países católicos por ela mais influenciados, zonas culturais e políticas onde laico e os seus derivados serão retirados do seu contexto religioso e sujeitos a uma releitura sobredeterminada pelos ideais de racionalidade, autonomia, emancipação, progresso e democratização, vindo a gerar expressões como laicidade, ou novas conotações em palavras como laicismo. Quer isto dizer que, naquelas regiões, as especificidades do processo secularizador, assim como das suas traduções como laicidade e laicismo, são parte do confronto entre Roma e a Modernidade, tensão bem ilustrada pelas anatematizações lançadas pelo Papado, horizonte polémico já distante para os protestantes.

Alguma teologia contemporânea recorre ao conceito de "fundamentalismo" (surgido nos princípios do século XX) para caracterizar essas posições. Recorde-se que Pio VI (1775-1799) qualificou os direitos de liberdade e igualdade como insensatos (carta Quod aliquantum, de 10 de Março de 1791) e, dois anos depois, vinculou o catolicismo ao absolutismo e prognosticou que os princípios consignados na Declaração Universal dos Direitos do Homem e do Cidadão levariam à barbárie. Críticas ao

(105) Telmo Verdelho, art. cit., p. 28. 
pensamento liberal nortearam a encíclica Ubi primum (1824), e, por sua vez, Gregório XVI (1831-1846) condenou, na Mirari vos (15 de Agosto de 1832), escrita contra Lamennais, e na Singulari nos (1834), o galicanismo, o racionalismo e o indiferentismo, assim como a liberdade de consciência e de opinião. Pio IX (1846-1878) reafirmou teses análogas na encíclica Nostis et nobiscum (1849), e, na Quanta Cura, seguida do Syllabus (1864), anatematizou o panteísmo, o naturalismo, o racionalismo absoluto, o racionalismo moderado, o comunismo, as sociedades secretas, as sociedades bíblicas, as sociedades liberais, a autonomia das leis morais em relação à lei divina, a autonomia da filosofia e da ética, a liberdade de pensamento, de opinião, de religião, de cultos, a reconciliação com o progresso. O Pontífice Romano não podia, nem devia transigir "com o liberalismo e com a civilização moderna". A par destas declarações, o mesmo reinado impôs a dogmatização da Imaculada Conceição (1854) e, no Concílio Vaticano I (1870), consagrou a infalibilidade papal. Leão XIII manteve análogas prevenções em relação à Modernidade, pois redefiniu a religião católica como a única verdadeira, rejeitou o princípio da tolerância (porque o seu relativismo colocaria as religiões num plano de igualdade), atacou o liberalismo e o socialismo, e as liberdades de pensar, de escrever e de culto não seriam direitos que a natureza deu ao ser humano, embora pudessem ser moderadamente tolerados (Quod apostolici muneris, de 28 de Dezembro de 1878, e Libertas praestantissimum, de 1888). Pio $X$ (1903-1914) confirmou as condenações anteriores no Juramento antimodernista (1 de Setembro de 1910) e, através do Decreto do Santo Ofício Lamentabili (1907) e da encíclica Pascendi domini gregis (1907), afastou os mais importantes teólogos modernistas (Alfred Loisy, Edouard Le Roy, Ernst Dimmet e Albert Houtin), impôs juramentos de fidelidade aos clérigos e colocou 150 obras no Index ${ }^{(106)}$.

\section{A dicionarização de "laicidade" e de "laicismo"}

Em Inglaterra, a primeira ocorrência de que há conhecimento do vocábulo laicism data de 1796. Por sua vez, em França, o suplemento do

(106) Sobre todo este fundamentalismo católico, veja-se Juan José Tamayo, ob. cit., pp. 81-87, 182. 
Dictionnaire da Academia, de 1842, utilizou os neologismos laïcisme, laïciste, igualmente para designar a doutrina religiosa "qui reconnaît aux laïques le droit de gouverner l'Église, d'ordoner les prêtes, d'élire les évêques, et, en certains cas, d'administrer les sacrements". E este significado ainda é reproduzido na edição de 1869 do célebre Dictionnaire de Littré. Porém, o campo semântico ir-se-á modificar sob o impacto das lutas (e controvérsias) provocadas pela Comuna de Paris, pela contestação feita à Ordem Moral (coligação conservadora e monárquica que, até 1876, tentou bloquear a republicanização do regime saído da queda do II Império), e pela política cultural da III República.

A partir de 1871, emergiu laicidade, termo integrado, em 1873, no Grand Dictionnaire de Larousse que esclarecia assim as novas acepções: "Laïcité: Caractère de ce qui est laïque, d'une personne laïque: la laïcité de l'enseignement. Il fut un temps où la laïcité était comme une note d'infamie. Laïque: Qui n'est ni ecclésiastique, ni religieux: juge laïque. 'Il ne doit pas y avoir un citoyen, clerc ou läque, qui soit soustrait à l'action des lois' (Dupin). Habit laïque - Biens laïques - Enseignement laïque. 'Le Dieu vivant est désormais plutôt avec le monde laïque qu'avec le monde ecclésiastique' (Quinet). 'L'esprit du gouvernement est un esprit laïque, la loi est indifférente' (E. Laboulaye)".

Littré regista-o (no suplemento de 1877, do seu Dicionário), ao citar o jornal La Patrie (de 11 de Novembro de 1871) que noticiou um debate, ocorrido no Conselho Geral do Sena (8 de Novembro), nestes termos: "Laïcité. Caractère Laïque [qui n'est ni ecclésiastique ni religieux]. Au sujet de l'enseignement laïque.... le Conseil [général de la Seine] a procédé au vote sur la proposition de laïcité, qui a été repoussée"'. E, em 1888, Larousse dicionarizou laïcisation e laïciser com a seguinte definição: "Rendre laïque, indépendent à l'égard de tout confession, de tout principe à caractère religieux".

Estes vocábulos, presumivelmente por influência da política francesa, encontraram eco em inglês. Por exemplo, laicization teve algumas ocorrências a partir de 1881, e laicize, de 1870 . Não por mera coincidência, registe-se que a sua aplicação também privilegiava o campo da educação e do ensino. Explica-se. Foi nos inícios da década de 1870 que a laicidade ganhou curso dentro da querela sobre a secularização do ensino. Na mencionada discussão parisiense (havida no Conselho Geral do Sena), o jornal que a publicitou ainda punha o conceito entre parêntesis, escrevendo: "le conseil a procédé au vote sur la proposition de laïcité, 
qui a été repoussée" ${ }^{\prime(107)}$. De qualquer modo, a sua imediata dicionarização (Larousse, Littré) também indica que ele rapidamente ganhou uma operatividade não só lexical, mas, sobretudo, de ordem político-ideológica(108), necessidade menos premente nos países protestantes.

Portugal não fugiu à regra. Ao que parece, designações como as de Estado laico ou laicismo não apareceram com muita frequência até aos princípios do século XX. A primeira foi detectada em 1885 , não por acaso, num jornal republicano e anticlerical (O Século), mas a sua maior utilização, na linguagem erudita, foi um pouco mais tardia ${ }^{(109)}$ : somente se deu por volta de 1902, isto é, quando se agudizou a crise (religiosa, política, social) que terminará na revolução republicana de 5 de Outubro de 1910.

Em suma: em França (assim como em alguns países por ela influenciados), termos como sociedade laica, Estado laico, ensino laico, laicidade, laicismo, laicizar, laicização foram-se impondo como vocábulos que também constituíam armas de luta contra a influência do clero e da Igreja católica e, nas suas versões mais radicais (agnósticas e ateias), contra a própria religião. No plano inverso, tais expressões apareciam aos católicos - na reacção do senador Delsol (1879), ao atacar Jules Ferry depois de este ter utilizado o neologismo "laïcisation" - como invenções ímpias, isto é, como "Barbara res, barbara vox"(110), qualificação que aquele não alterou quando o ministro a corrigiu através do termo "laïcité".

A nova terminologia, conquanto não rejeitasse ou substituísse a que tinha origem em saeculum - em Portugal, por exemplo, o termo secularização continuará a ser aplicado, mesmo pelos sectores anticlericais, como sinónimo de laicização -, denota o propósito de se dar um sentido mais político à demarcação entre o religioso e o profano, o público e o privado.

(107) In Pierre Fiala, art. cit., pp. 49-50, n. 1.

${ }^{(108)}$ Sobre os combates pela secularização e laicidade em França, vejam-se: 0 clássico estudo de Georges Weill, Histoire de l'idée laïque en France au XIX' siècle, Paris, Alcan, 1929; Louis Capéran, L'Invasion laïque. De l'avénement de Combes au vote de séparation, Paris, Desclée de Brower, 1935; Louis Capéran, Histoire contemporaine de la laïcité française, 3 vols., Paris, Marcel Rivière, 1957, 1959, 1961; Jacqueline Lalouette, La Libre-pensée en France. 1848-1940, Paris, Albin Michel, 1997; Jean-Marie Mayer, La Question laïque XIX-XX' siècle, Paris, Fayard, 1997.

${ }^{(109)}$ Cf. Mário Vilela, “Leigo e secular. Estado semasiológico e onamasiológico (1850-1910)", Sillages, n. ${ }^{\circ}$ 50, 1977, p. 16.

${ }^{(110)}$ In Pierre Fiala, ob. cit., p. 49. 
Dir-se-ia que não bastava realizar a separação. Ter-se-ia de ir mais longe, pelo que se apelava para que o Estado desempenhasse acções positivas - sobretudo ao nível da luta pela hegemonia no campo do poder espiritual -, em ordem a laicizar-se a sociedade ${ }^{(111)}$, isto é, a criar-se as condições (culturais, político-jurídicas e sociais) necessárias à concretização das promessas emancipatórias da Modernidade.

Todavia, a evolução semântica também mostra que, a par da questão do ensino, foi no terreno do combate pela desconfessionalização do poder político que aquelas expressões se consolidaram (alvo sem sentido em Inglaterra). Littré aplicou laicidade para qualificar o Estado enquanto instituição religiosamente neutra. E o Dictionnaire de pédagogie et d'instruction primaire (publicado a partir de 1882) reforçou a ideia segundo a qual o conceito definia bem a independência que aquele teria de manter em relação às Igrejas e a todas as crenças. Para o seu autor, o vocábulo laicidade "est nouveau et quoique correctemente formé, il n'est pas encore d'un usage général. Cependant le néologisme est nécessaire, aucun autre terme ne permettant d'exprimer sans périphrase la même idée avec ampleur". Não admira, dado que, para Ferdinand Buisson, ele era, sobretudo, o resultado da secularização do Estado e dos seus efeitos na revolução escolar. Daí, a sua convicção: "La notion fondamentale de l'État laïque, c'est-à-dire la délimitation profonde entre le temporel et le spirituel, est entrée dans nos moeurs de manière à n'en plus sortir"(112).

A consciência de que certas palavras não eram politicamente irrelevantes também pode ser ilustrada na Constituinte portuguesa de 1911, através da controvérsia havida entre dois deputados republicanos, a propósito do ensino. Se a maioria irá optar por "neutro", em vez de laico, alguns lembravam que este foi criado para significar, explicitamente, "o ensino livre de doutrinas religiosas. Depois esse termo foi desvirtuado pelo catolicismo, que o apoda de sectário". Um deles mostrava-se mesmo intransigente nesta matéria, declarando-se-lhe fiel, porque, com ele, a República Portuguesa conservaria "a sua pureza primitiva, pensando que o ensino leigo é de facto neutro em matéria religiosa"(113).

(111) Renan utilizou esta expressão, em 1887, para caracterizar "la tendance que porte le $19^{e}$ siècle à tout laïciser" (in Pierre Fiala, art. cit., p. 51 nota 3).

(112) In Dominique Gros, art. cit, p. 52.

(113) Diário da Assembleia Constituinte, sessão n. ${ }^{\circ} 31$, de 26 de Julho de 1911, pp. 16-17. 
Em suma: para este sector, "o termo laico [em itálico no original] não é senão uma delimitação, uma melhor definição de neutro", acepção fixada, pelo menos, "desde os célebres discursos de Ferry, na câmara francesa, em 1881"(114).

De qualquer modo, a história desta terminologia também revela algo indiscutível: foi a questão do ensino que a forjou, embora no contexto da afirmação da prioridade lógica da liberdade de consciência e de pensamento sobre as demais, cuja evolução irá para além da acepção de indiferença, impondo-se como um projecto positivo que exigia acções supletivas do Estado, em particular no campo da "formação das almas". E pode dizer-se que o cumprimento desta vocação traduzia o papel seminal que a cultura republicana (à francesa) ${ }^{(115)}$ atribuía aos problemas da educação e do ensino.

Na verdade, é um facto que, nos países em que esta orientação mais medrou (França, Espanha, Itália, Portugal, Bélgica) ${ }^{(116)}$, o caderno reivindicativo da laicidade ultrapassava os limites da separação à americana. É que, bem vistas as coisas, ele envolvia uma concepção totalizadora do mundo e da vida (incluindo a própria morte), mundividência que a futura acção activa do poder político - sobretudo através da educação e do ensino ("Estado-pedagogo", ou, segundo outros, "Estado-reitor") teria de tornar hegemónica, a fim de elevar os indivíduos a cidadãos patriotas e racionalistas, e de, à luz de uma moral cívica e social (teoricamente) tolerante, os mobilizar para práticas que, em alguns casos, punham em acção uma espécie de "religião laica"(117).

(114) João de Barros, A Educação moral nas escolas primárias, Paris-Lisboa, 1914, p. 19. Cf. Fernando Catroga, O Republicanismo em Portugal. Da formação ao 5 de Outubro de 1910, 2. ${ }^{a}$ ed., Lisboa, Editorial Notícias, 2000, p. 252.

${ }^{(115)} \mathrm{Cf}$. Claude Nicolet, L'Idée républicaine en France. Essai d'histoire critique, Paris, Gallimard, 1982.

(116) Cf. AAVV., La Laïcité, Paris, 1960; para o caso italiano, leiam-se, T. Tomasi, L'Idea laica nell'Italia contemporanea (1870-1970), Florença, La Nuova Italia, 1971;

G. Verucci, L'Italia laica prima e dopo l'Unità 1848-1876. Anticlericalismo, libero pensiero e ateismo nella società italiana, Roma-Bari, Laterza, 1981; S. Pivato, Clericalismo e laicismo nella cultura popolare italiana, Milão, Franco Angeli, 1990. 1980.

(117) J-M Mayer et al., Libre-pensée et religion laïque en France, Strasbourg, Cerdic, 
Nesta ordem de ideias, entende-se que um dos seus principais doutrinadores tivesse sentido a necessidade de remontar às raízes etimológicas, para relembrar a vocação democrática do projecto. Para isso, sublinhou que, para além da expressão latina laicus, laicidade vinha da palavra grega laós, que designava o "povo" e, em concreto, a massa popular, de onde o clero se foi hierarquizando no seio das comunidades cristãs primitivas. Esse seria o verdadeiro significado de laïque, que se opunha a clérical, como lai a clerc $^{(118)}$. No entanto, e como facilmente se aceita, esta digressão estava intimamente comandada pelo propósito de contrapor a laicidade ao clericalismo, ou melhor, ao "espírito clerical", que Buisson caracterizou como "la prétention d'une minorité à dominer la majorité au nom d'une religion". Diferentemente, "les laïques, c'est le peuple, c'est la masse non mise à part, c'est tout le monde, les clercs exceptés, et l'esprit laïque, c'est l'ensemble des aspirations du peuple, du laos, c'est l'esprit démocratique et populaire"(119).

\section{Clericalismo e anticlericalismo}

É verdade que as reacções contra os clérigos são antigas e de motivação variada. Durante séculos, elas situaram-se no "interior" da própria crença, limitando-se a canalizar descontentamentos em relação aos abusos de poder e à moralidade de alguns sacerdotes ${ }^{(120)}$. Estas manifestações são habitualmente apelidadas de "anticlericalismo popular", ou "anticlericalismo de leigos", e não podem ser confundidas com as que, a partir do século XVIII, não só se situarão "fora", mas também "contra" a Igreja. Por outro lado, também existiu algum "anticlericalismo" entre o próprio clero (regular e secular). De qualquer modo, a longa tradição do "anticlericalismo popular", alicerçada na denúncia dos costumes dos clérigos e numa certa sexualização do seu comportamento (consubstanciada na confissão), prolongar-se-á, podendo mesmo dizer-se que a posterior versão mais politizada se servirá do seu imaginário, predomi-

${ }^{(118)}$ In Pierre Fiala, art. cit., p. 53.

(119) In Idem, ibidem.

${ }^{(120)}$ Cf. P. A. Dykema e H. A. Oberman (eds), Anticlericalism in the late and modern Europe, Leiden, E. J. Brill, 1993. 
nantemente masculino, para alargar a sua recepção ${ }^{(121)}$. Os combates pela secularização e pela laicização da sociedade e do Estado trouxeram, contudo, novos significados a estas críticas, mudança que se exprimirá no aparecimento de um vocabulário próprio, tendo o termo "clericalismo", ao que parece, precedido o de "anticlericalismo". No entanto, ambos nasceram como irmãos siameses, já que, como salientou Alfred Loisy, o primeiro teve necessariamente de gerar o segundo ${ }^{(122)}$.

Significativamente, tais expressões tiveram o seu parto num momento em que o optimismo acerca das possibilidades de, finalmente, a Igreja se compatibilizar com o século (sonho de algum romantismo social), deu lugar à intensificação da recusa das ideias e valores da Modernidade por parte do Papado, atitude objectivada, na conjuntura em análise, e como se assinalou, na encíclica de Pio IX, Nostis et nobiscum (1849) - onde já se anatematizava o socialismo -, na confirmação do dogma da Imaculada Conceição (1854), nos anátemas do Syllabus contra errorum (apêndice à encíclica Quanta cura, de 1864) e na reafirmação da infalibilidade do Papa e do tomismo como "filosofia perene" (Concilio Vaticano I, 1870).

A expressão "clericalismo" teve o seu berço concreto em 1855, nas páginas de um periódico ligado ao emergente movimento livre-pensador belga. E a primeira utilização das novas conotações, com repercussões na opinião pública, foi feita por Sainte-Beuve, no parlamento (1868). O cardeal Donnet reprovou o facto de ele várias vezes ter falado em "clerical" de um modo injurioso, tendo o visado retorquido que a palavra "estava em circulação". Seja como for, o substantivo só ganhou uma maior visibilidade no discurso político dos inícios da década de 1870, isto é, no contexto da Comuna de Paris e das acções secularizadoras (lideradas pelos blanquistas) e, sobretudo, a partir do célebre grito de combate lançado por Gambetta em 1877: "le cléricalisme, voilà l'ennemi!".

A dicionarização deste alargamento semântico deveu-se, igualmente, a Littré que, em 1877, deu guarida aos neologismos "cléricalisation", "cléricaliser", "anticlérical" e, como se sabe, "laïcité". Como facilmente se aceita - tanto mais que ele foi um dos principais ideólogos da

${ }^{(121)}$ Cf. Julio de la Cueva Merino, Movilización politica e identidad anticlerical, Rafael Cruz (ed.), "El anticlericalismo", Ayer, n. 27, 1997, pp. 120-121.

${ }^{(122)}$ Cf. Alfred Loisy, L'Église et la France, Paris, Émile Nourry, 1925, p. 114. 
III República -, "l'engagement idéologique est ici sensible. Tous ces termes fourniront dans les décennies suivantes les supports lexicaux des grands débats polémiques entre républicains laïcisateurs et conservateurs cléricalistes"(123).

De qualquer maneira, alguns adeptos da laicidade não deixaram de se interrogar acerca da utilidade de termos tão marcados pelas tensões que lhes deram origem. Foi o caso de Ferdinand Buisson. Este via o anticlericalismo como uma expressão reactiva, soando a palavra de guerra, com um sentido estreito e agressivo, logo, pouco apta para objectivar propósitos construtivos. No entanto, também acabava por reconhecer que o seu sucesso lexical era o sintoma de um dos aspectos mais marcantes de mentalidade francesa dos finais de Oitocentos e inícios do século $X X^{(124)}$.

A esta luz, é lógico que o anticlericalismo se tenha definido em correlação com o diagnóstico que os seus adeptos faziam do clericalismo, conceito que, segundo Joseph Leclerc, referencia a intenção que uma Igreja ou uma sociedade espiritual manifestam para se envolverem nos assuntos seculares, com o fito de transformarem a autoridade pública num simples instrumento dos seus desígnios ${ }^{(125)}$. Porém, esta qualificação peca por ser um pouco limitada, pois não equaciona a circunstância de a vida social não se reduzir à esfera pública e de o poder não se esgotar no poder de Estado. Defende-se, assim, que, para a compreensão do fenómeno, se impõe relacioná-lo, igualmente, com a privacidade (dos indivíduos e dos grupos) e com a questão da complexidade dos poderes, pois, como salientou René Rémond, se é certo que o clericalismo (e, por conseguinte, o anticlericalismo) travou as suas principais "guerras" no terreno directamente político, importa não olvidar que elas tinham em vista, em última análise, a conquista da hegemonia na "formação das almas". Na verdade, na dialéctica entre clericalismo e anticlericalismo, as incidências políticas somente pontuam a trama mais visível desse combate, pelo que a questão religiosa tem de ser equacionada como uma espécie de nó górdio em que os problemas político-ideológicos, económico-sociais, culturais e simbólicos

(123) Pierre Fiala, art. cit., p. 49.

(124) Ferdinand Buisson, "La crise de l'anticléricalisme", Revue Politique et Parlamentaire, Octobre, 1903, p. 6.

${ }^{(125)}$ Cf. Joseph Leclerc, "Anticléricalisme", Catholicisme, t. ${ }^{\circ}$ II, cols. 1235-39; L'Église et la souveraineté de l'État, Paris, Flammarion, 1944. 
tensionalmente confluíram ${ }^{(126)}$, vindo a objectivar-se, nos países dominantemente católicos (em particular no Sul da Europa), em programas políticos empenhados em acelerar o processo secularizador.

Em nome da prioridade absoluta da liberdade de consciência e de pensamento, bem como da afirmação do princípio da soberania nacional e da cidadania, o anticlericalismo encorporou os legados do anti-ultramontanismo, do antijesuitismo e do anticongreganismo anteriores e inseriu-os num projecto político-cultural em que já não bastava pugnar, como havia pedido Voltaire, para que se esmagasse a "infame". Nas últimas décadas de Novecentos, a sua linha mais forte identificou-se com o livre-pensamento, transformando-se num movimento de "descristianização" (conceito posto a circular por alguns estudos saídos no período da II Guerra Mundial e, depois, pelo Centre de Sociologie des Réligions, dirigido por Gustave Le Bras, para referenciar o crescimento da irreligiosidade nas massas urbanas de Paris e seus arredores ${ }^{(127)}$, mas cuja pertinência - defendida por autores como Michel Vovelle ${ }^{(128)}$ - foi contestada por Delumeau ${ }^{(129)}$, sobretudo quando aplicada à caracterização das relações entre as elites secularizadas dos séculos XVII e XVIII e o catolicismo).

Seja como for, tudo isto mostra que a história de vocábulos como clericalismo, laicidade, laicismo é inseparável do contexto polémico que lhes deu luz. Daí que, e como o caso português também mostra, eles tenham aparecido para nomear, não algo interior à comunidade dos crentes, mas "o mundo de ideias não religiosas, ou mesmo anticlericais e anti-religiosas". Produtos "do liberalismo e do naturalismo, do positivismo e do livre-pensamento", expressões como laico, laicidade, laicismo "andavam no ar, caíram sobre leigo que sobrecarregavam de adjectivos ou substantivos como contextos sintagmáticos explicativos" (130). E, como se sabe, a agudização da questão religiosa nos finais do século XIX e inícios do século $\mathrm{XX}$, nos países dominantemente católicos, conduziu à sua crescente articulação com a questão social e com a questão do regime e,

(126) Cf. René Rémond, L'Anticléricalisme en France. De 1815 à nos jours, Paris, Éditions Complexe, 1985, p. 7 ss.

${ }^{(127)}$ Cf. Jean Pierre Sironneau, ob. cit., p. 137.

${ }^{(128)}$ Cf. Michel Vovelle, Piété baroque et déchristianisation. Les attitudes devant la mort en Provence au XVIII siècle, Paris, Hachette, 1976.

${ }^{(129)}$ Cf. Jean Delumeau, "Au sujet de la déchristianisation", Revue d'Histoire Moderne et Contemporaine, t. ${ }^{\circ}$ XXII, janvier-mars, 1975, p. 57 ss.

${ }^{(130)}$ Mário Vilela, art. cit., p. 16. 
consequentemente, "ao amadurecimento da ideologia laica, que obrigava ao exclusivismo de um termo e, por outro lado, o seu uso trazia tal conotação de luta, de ideologias e de argumentos presos ao fr. laic e laïque e ao it. laico, que servir-se do significante, era amuleto contra os adversários e identificação para os apaniguados"(131).

\section{A laicização externa e interna}

Por diferentes que tenham sido as modalidades deste embate, elas não podem fazer obscurecer os fundamentos e as expectativas que norteavam a laicidade como projecto. Parece evidente que este prometia criar as condições para que o indivíduo pudesse ascender, em liberdade (de consciência, de pensamento, religiosa), ao gozo dos seus direitos. Pelo que reivindicava os efeitos da secularização: a separação entre a esfera política e a religiosa, a pública e a privada; a privatização das crenças; a afirmação da autonomia do homem perante a justificação transcendente da ética, do conhecimento e das expectativas humanas. Por outro lado, não se estranha que os seus prosélitos tivessem, como alvo polémico, aqueles que encarnavam o obscurantismo e a intolerância e, portanto, impediam o progresso e a emancipação. E explica-se que as necessidades de legitimação histórica os levassem a invocar, como precursores, ideias, acontecimentos e personagens que marcaram, muitas vezes de um modo trágico, esses combates. Pode mesmo sustentar-se que a laicidade era reivindicada como o requisito dos requisitos para que, finalmente, fosse possível cumprir, a partir de garantias constitucionalizadas e de políticas educativas de inspiração democrática, o ideal de tolerância (civil e religiosa) em toda a sua extensão.

(131) Idem, ibidem, p. 7. Para uma análise do modo concreto como o anticlericalismo se concretizou em alguns países dominantemente católicos, vejam-se: Fernando Catroga, O Livre-pensamento contra a Igreja, cit.; Maria Lúcia de Brito Moura, A Guerra religiosa na Primeira República, Lisboa, Editorial Notícias, 2004; Jacqueline Lalouette, La Libre-pensée en France 1848-1940, cit.; Emilio da Parra Lopéz e Manuel Suárez Cortina (ed.), El Anticlericalismo español contemporáneo, Madrid, Editorial Biblioteca Nueva, 1998; Rafael Cruz (ed.), "El anticlericalismo", Ayer, n..$^{\circ}$ 27, 1997, passim; G. Verucci, L'Italia laica prima e dopo l'Unità 1848-1876. Anticlericalismo, libero pensiero e ateismo nella società italiana, cit.; S. Pivato, Clericalismo e laicismo nella cultura popolare italiana, cit. 
Ela não se inspirava numa filosofia fechada e sistémica. Mas, nas disputas contra o principal adversário-o clericalismo-, os seus ideólogos evocavam uma tradição que tivera o seu momento inaugural na filosofia grega, mas que passava por todos os teorizadores da liberdade de consciência (Pierre Bayle) e de pensamento (Espinosa), pelo ideal moderno de tolerância (Bayle, Lessing, Locke, Voltaire), pelo racionalismo crítico (Descartes, Kant), pelas lições das revoltas religiosas contra Roma (que desaguarão nas Igrejas reformadas), bem como pela revolução científica e pela secularização dos fundamentos do jusnaturalismo e do jusracionalismo, em suma, por tudo o que pudesse credibilizar as arremetidas contra o dogmatismo. Ganha assim sentido que igualmente exaltassem a memória das vítimas da intolerância, encarnada nos perseguidos e condenados pela Inquisição, ou por outros despotismos. Como exemplos, citava-se a matança do dia de Saint-Barthélemy (Agosto de 1572), a perseguição a Galileu, os suplícios, na fogueira, de Giordano Bruno (Roma, 1600), de Vanini (Toulouse, 1619), de Jacques Gruet (1547) e de Michel Servet (em 1553, às mãos dos calvinistas), assim como a decapitação de Calas (1762), que Voltaire denunciou no seu Tratado sobre a tolerância, a condenação de De La Barre (1766) e as vicissitudes por que passou o Édito de Nantes, desde a sua aprovação, em 1598, até à sua revogação, em 1685.

Em termos filosóficos mais concretos, os defensores da laicidade viam a génese da sua "filosofia", tanto no "conhece-te a ti mesmo" de Sócrates e na sua fidelidade aos valores éticos contra as convenções, como no racionalismo de Aristóteles e na reactualização do legado cultural greco-romano feita pelo Humanismo e pela Renascença. Nesta ressurreição, enraizavam, igualmente, as inquietações intelectuais de um Erasmo, de um Pico de la Mirandola, de um Rabelais, a dúvida metódica de Descartes e o panteísmo racionalista de Espinosa. Alicerces de onde teriam brotado a ciência moderna (Ambrósio Paré, Copérnico, Kepler, Galileu) e um conceito de Estado definido como uma entidade soberana e, portanto, autónoma, não só em relação aos poderes temporais particulares, mas também - como Locke havia teorizado - à Igreja. Esta doutrina era filada em Dante, Marsílio de Pádua, Guilherme de Occam, nos legistas conselheiros de Filipe-o-Belo e, naturalmente, em Maquiavel, Hobbes, Bodin, Pufendorf, entre outros, isto é, nas concepções secularizadas do contrato social, fossem elas de cariz optimista (Locke, Espinosa, Rousseau), ou pessimista (Hobbes). Em suma: perante tal tipo 
de releitura teleológica do passado, compreende-se que o militantismo secularizador se assumisse como o herdeiro dos defensores da liberdade de consciência e de pensamento.

Dadas as características dos ramos desta árvore genealógica, muitos declaram-se, de facto, como "livres-pensadores", numa crescente articulação com uma filiação de cariz maçónico ${ }^{(132)}$. Em outro lugar ${ }^{(133)}$, sublinhámos que o uso do termo freethinkers ocorreu, pela primeira vez, em 1667, para caracterizar a atitude de membros da Royal Society, de Londres, pertencentes ao anglicanismo liberal. Posteriormente, alguns discípulos de Locke também foram apelidados de freethinkers, por defenderam o deísmo, a tolerância religiosa e a separação das Igrejas do Estado. Entre eles, contavam-se personalidades marcantes como John Tolland - autor da influente obra Christianity of mysterious (1696) - e Anthony Collins que, em 1713, publicou $A$ Discourse on freethinking, occasioned by the rise and growth of a sect call'd freethinkers.

Durante o século XVIII, a expressão (ou as suas traduções) quase não foi utilizada fora de Inglaterra. E sabe-se que, em França, nos finais de Oitocentos, libre-pensée ainda não existia, embora libre penseur tivesse aparecido, em 1784, sintomaticamente num prefácio a uma reedição do Tratado sobre a tolerância de Voltaire. Porém, ambas as designações só ganharão voga nos meados do século XIX, já que, nas décadas anteriores, o seu curso foi quase nulo. Encontram-se em escritos do dr. Acham-Bault (1840) e significativamente em Victor Hugo (1842) ${ }^{(134)}$. Depois, serão as preferidas para qualificar a atitude filosófica e o objectivo nuclear da laicidade.

A ascensão ao uso autónomo da razão, na determinação de ideias e valores, exigia que o indivíduo se libertasse de um pensamento tutelado

(132) Sublinhámos esta vertente em Fernando Catroga, A Militância laica e a descristianização da morte em Portugal. 1868-1910, vol. 1, pp. 387-488 (Capítulo IV sobre "O Grande Oriente Lusitano Unido e o laicismo). Para França, veja-se Pierre Chevallier, Histoire de la franc-maçonnerie française. La maçonnerie: Église de la République (1877-1944), vol. 3, Paris, Fayard, 1975. Para Espanha, leia-se entre outros, J. A. Ferrer Benimeli (coord.), La Masonería en la España del siglo XIX, 2 vols., Valladolid, Junta de Castilla y Léon, 1987.

${ }^{(133)}$ Cf. Fernando Catroga, O livre-pensamento contra a Igreja, pp. 255-353.

${ }^{(134)}$ Cf. Pedro Alvarez Lázaro, Librepensamiento y secularización en la Europa contemporánea, Madrid, UPCO, 1996, pp. 181-183. Para o caso especificamente francês, leia-se Jacqueline Lalouette, ob. cit., p. 15 ss. 
(Kant, Jules Barni). Por isso, a conquista da separação do Estado e das Igrejas requeria a separação da Escola e das Igrejas, pois só a criação de um sistema de "educação nacional" e a neutralização religiosa da escola seriam capazes de fazer dos indivíduos seres racionais, ética e socialmente preparados para a prática dos seus direitos e deveres como cidadãos. Ideal que o ensino religioso - por ser intolerante, anti-racional, anti-nacional e anti-patriótico (porque ultramontano) - nunca poderia alcançar. E isto explica que, nos países em que a radicação do novo Estado-Nação teve de remover os interesses temporais das Igrejas dominantes, o problema da secularização (e o da laicidade) se tenha condensado, com alguma prioridade e dramatismo, na questão do ensino. Sinal evidente de que, se a antítese era de cariz social (bens materiais da Igreja) e político, o seu ponto crucial se encontrava, porém, na disputa pela hegemonia dentro do poder espiritual.

Condorcet havia proposto que não fosse admitido "dans l'instruction publique l'enseignement d'aucun culte", ideia retomada por Victor Cousine pelos grandes fundamentadores da cultura republicana oitocentista. Com efeito, na conjuntura da revolução de 1848, Edgar Quinet reivindicou, em nome da construção da cidadania, o ensino desconfessionalizado em oposição ao ensino das congregações, exigência que o movimento republicano, sob o Império, integrará no seu programa (Belleville, 1869) e que, uma vez no poder, Gambetta e, sobretudo, Jules Ferry (com o auxílio de Jean Macé, Ferdinand Buisson e da Ligue d'Enseignement) irão concretizar (lei 16 de Junho de 1881, que repôs o monopólio estatal dos graus e instaurou a gratuitidade absoluta do ensino primário dos 6 aos 13 anos $^{(135)}$; lei de 28 de Março de 1882, sobre a obrigação escolar; lei de 30 de Outubro de 1886, que proibiu os eclesiásticos de ensinar nas escolas públicas). A implantação, no terreno, da escola obrigatória, gratuita e laica gerou uma autêntica "batalha". Todavia, para os seus adeptos, o ensino "sans prêtes et sans catéchisme" constituía a pedra de toque de um ideal de pedagogia cívica que pretendia "fazer" patriotas e vincar a primazia dos valores da cidadania sobre as demais opções espirituais dos indivíduos. É que estas, em vez de gerarem consenso, dividiam. E só aqueles as poderiam pôr em coexistência, numa pacífica aceitação da tolerância filosófica, religiosa e política.

(135) Sobre os argumentos que serviam de arma de arremesso do clericalismo contra esta disposição, leia-se Dominique Gros, art. cit., pp. 60-61. 
Esta intenção foi necessariamente síntona com aquela outra que propugnava pela neutralização religiosa do Estado. Também aqui as raízes se, teoreticamente, podem remontar a Locke, no campo político, encontram-se na Revolução, experiência interrompida pela Concordata napoleónica de 1801 (orientação prolongada nos acordos celebrados com protestantes e judeus). Este instituto, com pequenas alterações - e sem nunca pôr em causa o seu cariz galicano -, durará mais de um século (e nunca será revogado nas regiões da Alsácia e Mosella, bem como nas colónias), à excepção dos períodos revolucionários de 1848 e de 1870; só será abolido em 1905, com a aprovação da lei de separação das Igrejas do Estado (136).

Dentro deste projecto, não faltou, igualmente, a secularização dos fundamentos do casamento, em ordem a considerá-lo, antes de tudo o mais, um contrato civil. Essa foi a perspectiva consignada na Constituição de 1791 e no decreto de Setembro de 1792, que municipalizou os registos paroquiais, atribuindo às comunas o poder exclusivo de conservar o conjunto "des actes destinés à constater les naissances, les mariages".

O refluxo revolucionário virá a alterar algumas destas disposições, incluindo as respeitantes ao divórcio. Contudo, inseridas no programa geral de laicização da sociedade e das instituições, elas serão repostas em vigor no decurso da III República: em 1880, com o levantamento da proibição de se trabalhar ao Domingo e com a dissolução da Companhia de Jesus; em 1881, com a abolição do carácter religioso dos cemitérios; em 1884, com o restabelecimento do divórcio e com a supressão das orações públicas em todas as igrejas aquando das sessões parlamentares; em 1905, com a municipalização das pompas fúnebres ${ }^{(137)}$.

Por tudo o que ficou escrito, e situando a compreensão deste processo na média duração, ter-se-á de concluir que "la sécularisation de 1789 ... s'achève dans la séparation en $1905^{\prime \prime(138)}$. De qualquer maneira, esta afirmação, sendo correcta, peca por restringir as implicações do processo de secularização como laicidade e, sobretudo, como laicismo. É que, neste

\footnotetext{
${ }^{(136)}$ Cf. J.-M. Mayer, La Séparation des Églises et de l'État, Paris, Éditions Ouvrières, 1993.

(137) Sobre o processo laicizador em França, leiam-se: G. Bedouelle e J.-P. Costa, Les Laicités à la française, Paris, PUF, 1997; Jean Baubérot, Histoire de la laïcité française, Paris, PUF, 2000; J.-M. Mayer, La Question lä̈que (XIX et XX siècles), cit. ${ }^{(138)}$ Dominique Gros, art. cit., p. 55.
} 
caso, não se tratou de reivindicar somente - tal como alguns faziam em relação à esfera económica - uma atitude negativa do Estado, tendo em vista a exclusiva garantia da liberdade religiosa. $O$ projecto apontava para funções positivas, pois, a par da laicidade institucional, pretendia-se laicizar a sociedade e as consciências individuais, porque se acreditava que só assim se conseguiria sapar o poder das forças que resistiam à modernização e se faria radicar o novo conceito de soberania cidadã.

Sintetizando o que foi defendido pelos movimentos políticos (monárquicos liberais de esquerda, republicanos, socialistas, anarquistas) que inscreveram a laicidade nos seus programas, ou do que foi levado à prática (III República francesa, I República portuguesa, revolução mexicana, II República espanhola, etc.), detecta-se, como programa comum, o propósito de transformar as relações institucionais entre o Estado e as Igrejas e de inocular novas ideias, valores e comportamentos. Embora de um modo não homogéneo quanto a fundamentos, meios e objectivos, todos eles reivindicavam: a separação das Igrejas do Estado, fosse como Igreja livre no Estado livre (proposta avançada pelo catolicismo liberal desde o "segundo" Lamennais), ou como Igrejas livres no Estado livre (preceito defendido pelo espiritualismo republicano, bem representado por Jules Simon), ou como Igrejas livres no Estado neutro, indiferente ou laico (posição que se tornou dominante); a separação das Igrejas da Escola, concretizada na implantação da obrigatoriedade, gratuitidade e laicidade do ensino, bem como na secularização do corpo docente ${ }^{(139) ;}$ a separação das Igrejas da Familia, garantida pela introdução do casamento civil e do divórcio; a separação da Igreja e da saúde, conseguida através da proibição da enfermagem e da assistência religiosas nos hospitais.

Num registo mais cultual, também se desejava laicizar o capital simbólico, visando a produção (e reprodução) do consenso social e nacional, quer mediante a substituição de Deus pelo culto da Pátria e a abolição dos juramentos religiosos nos actos políticos e judiciais, quer através da instauração de feriados civis (extinguindo ou restringindo os religiosos) e da promoção de festas e de uma nova hagiografia cívica. E, neste intento de se mudar atitudes e comportamentos, igualmente se desejava sinalizar

(139) Cf. Pierre Chevallier, La Séparation de l'Église et de l'École. Jules Ferry et Léon XIII, Paris, Fayard, 1981; Dominique Gros, art. cit., pp. 51-63. 
a prioridade cívica dos ritos de passagem (nascimento, casamento e morte), com a introdução do registo civil obrigatório (acto que devia ser prévio às opções religiosas) e com a secularização dos cemitérios. Tudo isto, conjugado com as restrições impostas às manifestações exteriores de culto (procissões, uso de símbolos, etc.), e, nos casos mais extremos, acompanhado por manifestações de teor hagiofóbico e iconoclasta ${ }^{(140)}$, tinha por objectivo laicizar o espaço público e fazer refluir as opções e práticas religiosas para a esfera privada, não raro, em nome de um apelo a um renovação moral em que o exemplo de Cristo era criticamente confrontado com o "materialismo" dos que se diziam seus herdeiros.

É evidente que este programa ultrapassava, em muito, os limites das incidências político-jurídicas da secularização, pois articulava a laicização externa, de cariz mais institucional, com a laicização interna, empenhada em retirar à Igreja a sua antiga hegemonia na formação e atracção das almas. Por conseguinte, a conquista do poder político era condição necessária para que o Estado desempenhasse um papel activo na criação das bases legislativas e culturais adequadas ao cumprimento da constitucionalização das liberdades fundamentais (incluindo a liberdade religiosa) e de um ideal de tolerância balizado, porém, pelo respeito da soberania nacional e pelo imperativo de se formar cidadãos, alicerce de todos os direitos e deveres do homem. Só o poder político, em nome da soberania e da prossecução do bem comum, poderia arbitrar as diferenças e salvaguardar a paz civil. Para isso, a laicidade impunha-se como uma consequência lógica do direito público moderno, base legitimadora de um projecto político-jurídico em que a "razão legisladora" seria "razão legiferante", num trabalho de convergência dos ideais de democracia representativa, teoria do mandato, princípio de igualdade, emanações, em última análise, da soberania nacional, una e indivisível ${ }^{(141)}$.

(140) Cf. Manuel Ruiz Delgado, La Ira sagrada. Anticlericalismo, iconoclastia y antirritualismo en la España contemporánea, Barcelona, Ed. Humanidades, 1992; Las Palabras de otro hombre. Anticlericalismo y misoginia, Barcelona, Muchonick, 1993; "Anticlericalismo, espacio y poder. La destrucción de los rituales católicos. 1931-1939", Rafael Cruz (ed.), ob. cit., pp. 149-180; Luces iconoclastas. Anticlericalismo, espacio y ritual en la España Contemporânea, Barcelona, Editorial Ariel, 2001. Para o caso português, sob a I República, consulte-se Maria Lúcia de Brito Moura, ob. cit., passim.

${ }^{(141)}$ Dominique Gros, art. cit., p. 57. 


\section{Tolerância laica e intolerância laicista}

Neste contexto, não será errado dizer que a faceta externa da laicização reactualizava e radicalizava a proposta que Locke havia formulado acerca das relações entre a religião e o Magistrado. Por outro lado, ao ligar-se à luta pela liberdade de consciência (Pierre Bayle) e, sobretudo, de pensamento (Espinosa) - os seus prosélitos autodesignavam-se "livres-pensadores" -, enfatizava-se o problema educativo, num prolongamento das promessas emancipatórias feitas por alguns iluministas. De qualquer modo, estas filiações podem escamotear as diferenças que as novas mediações políticas introduziram no ideal moderno de tolerância.

Quanto aos seus fundamentos, o propugnado pela laicidade não postulava qualquer raiz divina como fonte de determinação ética, nem conferia valor sociabilitário às religiões transcendentes (ao invés do que havia defendido o anticlericalismo liberal). No fundo, próximo de Bayle e de Espinosa, ia mais longe do que Locke. Concretamente, aproximava-se do autor do Dictionnaire critique, dado que este, ao colocar o critério aferidor da tolerância, não na verdade, mas na sinceridade das opções, reconhecia a todas as escolhas que preenchessem essa exigência efeitos sociais positivos. E não se pode esquecer que a laicidade era pressuposto necessário para o enraizamento da virtus republicana, e que o seu sincrético fundo filosófico, que partia do deísmo e do espiritualismo neokantiano (a este título, veja-se a posição de J. Barni e de Renouvier), foi sendo hegemonizado por posições agnósticas e, nos seus sectores mais radicais, embora minoritários, ateístas-materialistas. Isto explica que, pelo menos no plano dos princípios, o reconhecimento da prioridade da liberdade de consciência implicasse a liberdade de pensamento e, consequentemente, o direito tanto à religião como à não religião, algo que, à excepção de Bayle, estava longe dos anteriores ideais de tolerância.

Alicerçada nos direitos fundamentais - que, recorde-se, o Papado ainda não aceitava -, a liberdade religiosa teria como limite a salvaguarda do pluralismo religioso, sendo intolerável somente o que, na sua prática, colocasse em causa a ordem pública. Este registo liberal surgia completado com um outro, que também tem de ser entendido à luz das resistências do catolicismo às ideias e valores de inspiração demoliberal e racionalista, a saber: a já assinalada acção positiva do Estado na criação das normas jurídico-políticas conducentes à implantação efectiva da liberdade religiosa e ao seu usufruto num plano de igualdade, e não de privilégio, 
mesmo que este fosse o da confissão maioritária sobre as minoritárias. O que, nos países dominantemente católicos, se mostrou ser incompatível com a sua total indiferença em relação a um terreno que as religiões também disputavam (o da educação e ensino), de modo a socializar-se uma moral que, ao cimentar a nova sociabilidade política-assente numa opinião construída pelo uso público da razão crítica e na soberania delegada pelos indivíduos-cidadãos -, realizasse a emancipação do laós, base material da constitucionalização formal dos direitos e deveres do homem e do cidadão.

Assim sendo, a laicização externa foi completada pela laicização interna, entendendo-se por que é que as suas principais batalhas foram (e são) travadas à volta da questão educativa, afinal a fonte de todos os poderes. De facto, nas experiências em que a secularização ganhou contornos de laicidade explícita, o novo Estado-Nação, para se implantar e defender, actuou directamente como "Estado-pedagogo", a fim de construir a cidadania, algo impossível se as consciências continuassem a ser hegemonizadas pelos valores religiosos, que também eram valores políticos e sociais, propugnados pelas Igrejas. Daí, o cariz paradoxal do conceito de neutralidade. É que, como explicava Jules Ferry, em 1883, "nous avons promis la neutralité religieuse. Nous n'avons pas promis la neutralité philosophique, ni la neutralité politique".

As dificuldades de modernização da sociedade e de enraizamento de uma ordem legitimada na soberania popular levaram a que a laicidade se afirmasse como um projecto totalizador, mas interessado em respeitar a autonomia do indivíduo e em fomentar a sua vocação associativa e sociabilitária, faceta imprescindível para a realização da cidadania. A seu propósito, pode mesmo falar-se - devido ao sincretismo dos seus fundamentos -, não de uma, mas de "filosofias da laicidade"(142), cujas diversidades pressupunham, porém, algumas notas caracterizadoras comuns $^{(143)}$. Politicamente, seguiam uma orientação republicana e entificavam a soberania do povo (o laós). Em termos educativos, defendiam

(142) Pierre Macherey, "Philosophies laïques", Mots, n. ${ }^{\circ}$ cit., pp. 5-21. Para um contacto com alguns dos textos decisivos da laicidade, leia-se Pierre Pierrard, Anthologie de l'humanisme laïque de Jules Michelet à Léon Blum, Paris, Albin Michel Spiritualités, 2000.

${ }^{\left({ }^{143}\right)}$ Cf. Edouard Tortarolo, Il Laicismo, Roma-Bari, Laterza, 1998. 
as capacidades libertadoras da educação (que se queria nacional), de molde a criar-se um "espírito público", ou melhor, uma "opinião pública" de cunho simultaneamente patriótico, democrático e cosmopolita. Para a consecução destes objectivos, criticavam os fundamentos éticos de inspiração transcendente em nome da autonomia da razão prática (kantiana), ou, o que se foi tornando dominante, de uma moral de cariz social e cívica apostada em harmonizar os direitos subjectivos do indivíduo com a sua vocação sociabilitária e humanitarista, finalidade que teve no solidarismo dos finais de Oitocentos o seu mais marcante ideário sociopolítico.

Mas é um facto que a laicidade foi igualmente animada por uma atitude muito prosélita, característica que acabava por recalcar a racionalidade que o seu discurso manifesto proclamava, porque eivada de "une idéologie religieuse, porteuse d'une force de conviction irrésistible parce qu'elle est soutenue par la certitude, antérieure à toute démonstration raisonnée, du progrès collectif"(144). Por isso, enformaram-na de algo parecido com o que combatia, ambiguidade, aliás, explicitamente assumida por alguns dos seus mais brilhantes doutrinadores. Esse também foi o caso de Ferdinand Buisson - autor de uma obra sintomaticamente intitulada La Foi laïque -, para quem a luta pela laicização da sociedade era um confronto de "foi contre foi: ou la foi religieuse ou la foi civique. Ou défendre les droits de l'Église, société d'origine divine et authorisée à commender au nom de Dieu, ou défendre les droits de l'homme garantis par les institutions démocratiques"(145).

Assim, não espanta que muitos dos seus adeptos tenham sido particularmente sensíveis à adopção de formas de religiosidade cívica ${ }^{(146)}$, práticas simbólicas que procuravam transformar o atomismo social em comunidade cívica. Desde a sua génese, a nova ordem política, ao pretender autonomizar-se do campo religioso, segregou ideias e práticas adequadas à sua reprodução. Encontram-se expressões desta necessidade em Rousseau e na "religião cívica" que o Estado americano criou (e recria), bem como

(144) Pierre Macharey, art. cit., p. 17.

${ }^{(145)}$ Ferdinand Buisson, Nouveau dictionnaire de pédagogie et d'instruction primaire, Paris, Hachette, 1911, p. 1403. Cf. Pierre Macherey, art. cit., p. 20.

${ }^{(146)}$ Cf. R. Jöel, "La laïcité comme religion civile", Esprit, n. ${ }^{\circ} 175,1991$, pp. 108-115. 
- embora num outro registo - nos novos cultos nascidos durante a Revolução Francesa. E sabe-se que, em França (e em outros países), com os avanços e recuos deste modelo, se institucionalizou, nas últimas décadas do século XIX, um sistema de festas inserido no projecto de educação nacional. Para muitos, estas liturgias - termo que tem o mesmo radical que laós ${ }^{(147)}$, , sobredeterminadas por uma moral social e crítica, bastariam para substituir as vivências religiosas propriamente ditas, condenadas, pela evolução da própria história, à extinção e, transitoriamente, à esfera da vida privada e associativa.

Este teleologismo desaguava na relativização do religioso e, em muitos casos, em previsões segundo os quais a "religião do futuro" - tema muito debatido a partir da década de 1870 - acarretaria a extinção das religiões reveladas e anularia a necessidade das interrogações e atracções em relação ao sagrado. Embora a este modo de pensar se opusesse uma linha forte, constituída por defensores da laicidade de orientação mais espiritualista (à frente dos quais se deve colocar Jules Simon e, em Portugal, entre outros, Sampaio Bruno), o certo é que, numa corrente minoritária, mas ideologicamente muito influente, o laicismo era inferido a partir de posições agnósticas e ateias que acreditavam na cientificidade do prognóstico acerca da iminente "morte de Deus".

Naturalmente, esta ala não se satisfazia com a laicização externa. Esta devia ser acompanhada por uma completa laicização interna, indo mais longe do que o anticlericalismo liberal - que tinha sonhado com uma reforma do catolicismo que o compatibilizasse com a Modernidade -, ou do que o anticlericalismo republicano espiritualista, pois a sua crítica alvejava a própria ideia de Deus. Para a justificarem, recorriam, muitas vezes em coexistência, a teorizações inspiradas quer no método histórico-filológico aplicado aos textos sagrados (Renan), quer em argumentos antropológicos (Feuerbach), quer em teses de cariz filosófico-evolutivo (Bruno Bauer, David Strauss), ou de pendor histórico e sociologista (Comte, Letourneau, Durkheim), quer de teor naturalista (em que, como em Lombroso e seus seguidores, a sobrevivência do sentimento religioso era vista como uma "monomania" ou uma "patologia", atitudes passíveis de explicações antropométricas), quer, ainda, de índole filosófico-social

${ }^{(147)} \mathrm{Na}$ Grécia, as liturgias eram sinónimo de "serviço cívico". 
(Marx e, sobretudo, Proudhon), ou de base materialista (Büchner, Moleschott, etc.) $)^{(148)}$.

Muitas destas posições confluirão na defesa de um ideal que contraditava o antidogmatismo e a tolerância que reivindicava. Em nome da razão e, sobretudo, da ciência - ou melhor, da sua exploração ideológica -, elas recorriam a um conceito de verdade contrário ao cariz hipotético que esta possuía no trabalho científico propriamente dito, apresentando-a como um ditado definitivo e absoluto. O que fazia da laicidade uma fé, apta para incentivar a militância empenhada em acelerar a chegada do que se acreditava ser o inevitável sentido da história. Tudo isto, miscegenado com o campo das lutas político-ideológicas em que o projecto se inseria, levou a que, frequentemente, a proclamada tolerância se tivesse transformado em intolerância. Todavia, o contrário também foi verdadeiro: esta posição foi tanto mais radical quanto maior foi a resistência que a Igreja, em aliança, implícita ou explícita, com as forças mais retrógradas da sociedade, opôs à realização política de ideias e valores modernizadores, mesmo quando democraticamente legitimados, como se de uma nova "cruzada" ou de uma nova "guerra justa" se tratasse.

Aquele tipo de laicismo foi apanágio dos círculos mais declaradamente ateus, no seio dos quais, como salientámos em outro trabalho, a herança positivista, blanquista, proudhoniana e bakuninista foi sendo integrada numa dada interpretação de Marx e de outros materialistas. Neste modo de ver, Deus era apresentado como o símbolo justificador de toda a opressão, pelo que não bastava dizer, como alertara Gambetta em 1877, "le cléricalisme, voilá l'ennemi". Tal divisa devia ser completada por estas outras: "ni Dieu ni prêtres" (Proudhon), ou Homo sibi Deus (Pi y Margall), ou, na versão mais acrata, "ni Dieu ni maître"(149). Como quem diz: a emancipação (cultural, social e política) só seria completa com a "morte de Deus". Maneira de insinuar que, como o homem tinha sido "morto" para que Deus "vivesse", a futura libertação da humanidade só seria possível com o Seu imediato definhamento.

Apesar de tudo, é também verdade que a interpretação e a concretização do ideal de laicidade não foram homogéneas. $E$ basta lembrar as experiências históricas concretas para se detectarem clivagens internas

(148) Fernando Catroga, art. cit., pp. 281-282.

(149) Sobre tudo isto, veja-se Idem, ibidem, pp. 264, 281-282. 
(espiritualistas e neokantianos, ou, no caso espanhol, krausistas), como, por exemplo, a que opôs o republicanismo mais próximo de um conceito restrito de neutralidade às suas versões mais radicais. Por outro lado, ter-se-á de ter presente que estas especificidades ilustram bem as características das sociedades em que tiveram lugar e o grau de conflitualidade política e social que as determinou. Por exemplo, o caso francês - onde o processo demorou, em termos de decisões político-legislativas, cerca de trinta anos, numa sociedade em que as religiões minoritárias eram fortes (particularmente as protestantes) e em que os factores secularizantes (industrialização, urbanização, alfabetização) tinham um significativo desenvolvimento - foi diferente do que aconteceu nos países (Portugal, Espanha, México) que o escolheram como modelo. E as diversidades foram ainda maiores quando o laicismo foi praticado como uma espécie de "religião cívica de Estado", embora oficialmente de cunho ateísta, como aconteceu em muitas das experiências de implantação do socialismo, orientação que atingiu na Albânia a sua expressão mais radical.

Em França, depois de uma fase de hostilidade - polarizada à volta da questão escolar e da promulgação, em 1905, da lei de separação das Igrejas do Estado -, chegou-se, a partir da década de 1920, a uma tácita plataforma de entendimento. No entanto, periodicamente, a laicidade volta a ser problematizada, não por acaso, sempre à volta do problema do ensino $^{(150)} e$, mais recentemente, em consequência do impacto da inserção de minorias (engrossadas pela emigração) com opções e práticas religiosas ainda exteriores ou alheias às plataformas de pendor consensual criadas pela secularização e pela laicidade.

A tentativa portuguesa para se laicizar a sociedade e o Estado foi mais radical do que a francesa. Como a questão religiosa se transformou no nó de todos os conflitos, ganhou força a ideia de que a separação e a laicização (externa e interna) trariam a democracia política e social. Daqui decorreu um voluntarismo legislativo que fez com que, em sete meses (Outubro de 1910 a Abril de 1911), se tenha decretado o que, em França, demorou quase trinta anos. $\mathrm{E}$ isto num país dominantemente agrícola e analfabeto, no qual era fraquíssimo o peso das religiões não católicas, objectivamente aliadas da laicidade (não do laicismo) porque

(150) Cf. Jean Boussinesq, La Laïcité française, Paris, Seuil, 1994. 
interessadas em acabar com a confessionalidade do Estado e em implantar, de direito (e não como uma mera concessão), tanto a tolerância como a liberdade religiosa. Foi neste contexto que eclodiram as resistências do alto (bispos e Papado) e baixo clero, bem como das populações mais catolicizadas. $O$ que gerou situações de violência que não se resumiram a simples polémicas verbais, ou a agressões simbólicas (iconoclastias), pois provocaram muitos incidentes físicos e alguns mortos (nos primeiros anos da I República, à volta de uma dezena) $)^{(151)}$.

Em Espanha, o confronto foi mais extremado. Dir-se-ia que, na questão religiosa, embateram, tragicamente, as "duas Espanhas" com tudo o que as dividia, animadversão acentuada pela força que a Igreja detinha na sociedade e pela sua militante oposição aos ideais modernizadores ${ }^{(152)}$. Deste modo, quando se radicalizaram os conflitos sociais e políticos, ela foi um dos alvos privilegiados, pouco valendo as prevenções de socialistas como Pablo Iglesias, para quem o empolamento do problema só interessava aos que não queriam resolver a questão social. Os acontecimentos sangrentos da "Semana Trágica" de Barcelona, em 1909(153), e, sobretudo, os que, a despeito da posição de republicanos mais moderados, se desencadearam, sob a II República e por acção de milícias populares, foram o ponto de chegada de um antagonismo que vinha do século anterior. As medidas laicizadoras imediatamente tomadas pelo novo regime (1931), ligadas a outras, de cariz social e político, suscitaram reacções, fazendo engrossar a conspiração ultra-direitista, movimento que culminará na sublevação franquista de 18 de Julho de 1936 e na guerra civil que se the seguiu.

Foi neste clima bélico que a laicização desembocou numa violência sangrenta. Com efeito, durante aquele período, numerosos símbolos sagrados foram destruídos, sendo incendiadas ou fechadas centenas de igrejas e mortos 6832 membros do clero, 90\% dos quais em 1936. No número global, contavam-se 13 bispos, 4172 sacerdotes diocesanos e

(151) Acerca destas formas de violência, consulte-se, por todos, Maria Lúcia de Brito Moura, ob. cit., passim.

${ }^{(152)}$ Sobre este processo, veja-se Manuel Suárez Cortina (ed.), Secularización y laicismo en la España Contemporánea, Santander, Sociedad Menéndez Pelayo, 2001.

${ }^{(153)}$ Cf. J. C. Ullman, La Semana trágica. Estudio sobre las causas del anticlericalismo en España (1898-1912), Barcelona, Ariel, 1972. 
seminaristas, 2364 religiosos e 238 monjas ${ }^{(154)}$; o que representava $13 \%$ dos sacerdotes diocesanos de Espanha e $23 \%$ do clero regular, sendo a percentagem de monjas inferior a $1 \%{ }^{(155)}$.

Tudo isto mostra como é que a defesa de princípios decretados para salvaguardar a máxima tolerância possível se pode transmutar em intolerância e ter como contra-resposta uma intolerância ainda maior. Como se sabe, com raras excepções - e descontando o caso específico do País Basco-, a Igreja, através da mão militar dos insurrectos franquistas, virá a ser conivente, durante a guerra civil, com milhares e milhares de mortes sumárias, num ajuste de contas em que a política se confundiu com a religião, quase não havendo lugar para o perdão(156). Os bispos - ao qualificarem a subversão contra um regime democraticamente legitimado, na pastoral colectiva de 1 de Julho de 1937, como "guerra santa" movida aos "vermelhos" (expressão que diabolizava todos os republicanos) - e o próprio Papa, em concreto, através da sua alocução radiofónica de 1 de Julho de 1939, abriram o campo para que os vencedores justificassem a sua empresa como uma "cruzada", nomeadamente quando o sucessor de Pedro se deixou influenciar pelos bispos franquistas a um ponto tal que acabou por saudar a "vitória de Franco" e lançar a benção apostólica sobre os "queridos filhos da Católica Espanha, sobre o Chefe de Estado e seu ilustre Governo", sobre o "Episcopado e o abnegado clero", e "sobre os heróicos combatentes"(157), silenciando os derrotados.

Não é este o lugar para se descrever as transformações que se deram nas sociedades que sofreram processos fortes de laicização, assim como o modo como perdurou a memória desta "era de extremos". Contudo, quando as condições históricas se alteraram (ou consolidaram) num sentido

${ }^{(154)}$ Cf. Julio de la Cueva Merino, "Políticas laicistas y mobilización anticlerical durante la Segunda República y la Guerra Civil", Manuel Suárez Cortina (ed.), ob. cit., p. 272.

${ }^{(155)}$ Cf. Marcelino Flórez Miguel, Clericalismo y anticlericalismo. Las venganzas de 1936, Burgos, Editorial Dossoles, 2003, pp. 134-135.

(156) Cf. J. Casanova, F. Espinosa, F. Mir e F. C. Y. Moreno Gómez, Morir, matar, sobrevivir. La violencia en la dictadura de Franco, Barcelona, Crítica, 2002; $\mathrm{H}$. Raguer, La Pálvora y el incienso. La Iglesia y la Guerra Civil española (1936-1939), Barcelona, Peninsula, 2001; Santos Julia (ed.), Violencia política en España del siglo XX, Madrid, Taurus, 2000.

(157) In Marcelino Flórez Miguel, ob. cit., p. 234. Cf. H. R. Southworth, El Mito de la cruzada de Franco, Barcelona, Plaza y Janés, 1986. 
mais conservador e autoritário, a Igreja aproveitou para reconquistar posições, procurando, através da celebração de concordatas, lançar acções recatolicizadoras, mantendo-se alheia, porém, à problemática dos direitos do homem em geral, incluindo a da liberdade para as demais crenças. Foi o que fez com os Governos de Itália (1929), Alemanha (1933), Portugal (1940) e Espanha (1953). Sinal de secularização, este legado não foi posto em causa, no essencial, quando esses países se democratizaram, embora com reactualizações e num contexto em que a desdramatização da questão religiosa se deu num quadro em que a própria Igreja, finalmente, se declara respeitadora dos princípios fundamentais que o clericalismo havia combatido.

\section{A cidade de todos}

Em suma: parece indiscutível que a laicidade é inseparável do processo de construção do Estado-Nação, realidade política que, hoje, se encontra limitada, pois a soberania nacional é compartilhada por outros poderes, formais ou fácticos, que agem na ordem mundial. Por sua vez, o anticlericalismo político à século XIX parece extinto, talvez em consequência do facto de as Igrejas, e sobretudo a Igreja Católica, terem alterado o seu pensamento em relação a ideias e valores que, ainda há pouco tempo, anatematizavam. Porém, ficará sempre por saber se alguma vez elas lá chegariam sem a acção (apesar dos excessos) dos que lutaram pela secularização e pela laicidade.

Recorde-se que, em 28 de Abril de 1958, Pio XII, na sua alocução Alla vostra filiale rechiesta, reconheceu, dentro de certas condições, a laicidade do Estado como legítima, e que o Concílio Vaticano II se abriu à valorização cristã - atitude explicitada na Declaratio dignitatis humanae - de uma das velhas reivindicações da secularização e da laicidade: o direito que toda a pessoa humana tem à liberdade religiosa, num horizonte de livre busca da verdade e de reconhecimento dos "direitos alheios e seus deveres para com os demais e para com o bem comum de todos". Aquele documento, porém, nem sempre está escrito numa linguagem coerente e clara, e as decisões do Concílio não são consensualmente entendidas no interior do catolicismo. Certos sectores continuam a defender posições integristas, enquanto outros, sem alienarem, por inteiro, a herança do Concilio Vaticano II, fazem leituras restritivas dos seus ensinamentos e 
actuam de um modo crítico (e até persecutório) em relação às correntes (teologia da secularização, teologia da esperança, teologia da libertação, etc.) que procuram aprofundá-los. E as iniciativas apostadas em consolidar o diálogo inter-religioso não têm bastado para superar as resistências contra a aceitação do cariz plural e relativo do valor das religiões, o que revela a sobrevivência de um preconceito que há muito Locke captou nestes termos: "qualquer igreja é ortodoxa para si própria, errada ou herética para as outras; cada qual julga que aquilo em que acredita é verdadeiro e condena como um erro o que dela difere"(158).

Num outro registo, e para se dar resposta aos novos desafios, defende-se ser preciso proceder à revisão do próprio ideal de laicidade, porque, a par dos excessos que, em seu nome, foram cometidos, os seus pressupostos se basearam numa visão teleológica da história e numa antropologia que reduzia a humanidade do homem à racionalidade, prognosticando o inevitável refluxo da atracção pelo sagrado. Premissas de onde resultaram consequências políticas importantes, algumas delas filhas de um entendimento excessivamente "burguês" dos elos entre o espaço público e o privado, pois esquecia-se que, se o homem é lógos, ele também é homo ludens, homo loquens, homo symbolicus e homo religiosus, dimensões que ficarão diminuídas se não lhes for reconhecida expressão colectiva e aberta.

Levando tudo isto em conta, em França, fala-se na necessidade de se celebrar um novo "pacto laico", em que, sem se alienar a neutralidade do Estado como condição essencial de liberdade e de tolerância, se reconheça a dimensão pública e social das práticas religiosas; outros, porém, preferem manter-se fiéis à acepção oitocentista de laicidade, secundarizando a carga polémica e "religiosa" das lutas que lhe deram origem. Para evitar mal-entendidos, outros ainda, como Paul Ricoeur, em vez de "Estado laico", gostam mais de falar em "Estado de direito".

Por outro lado, o debate actual também não pode escamotear o condicionante assinalado: a laicidade (e, em certo sentido, a secularização) emergiu intimamente ligada à génese e consolidação do Estado-Nação, entidade imaginada como um corpo consensual e homogéneo. Contudo, o crescimento das diversidades (étnicas, religiosas, culturais) e a edificação de comunidades políticas mais globais (exemplo: a União Europeia, ou a reivindicação de uma espécie de constitucionalização de direitos e

(158) John Locke, ob. cit., p. 98. 
deveres cosmo-políticos, conferindo prioridade, em certas matérias, ao direito internacional) introduziram novas necessidades de coexistência. O que colocou na ordem do dia o multiculturalismo, seja no interior de cada sociedade nacional, seja nas suas correlações exteriores. E, nestes encontros (e desencontros), a própria Europa surge, em relação a si mesma, como um mosaico político-cultural, incluindo o desenhado pelas várias modalidades de relacionamento das Igrejas com o Estado.

Quanto a esta questão(159) , François Champion distinguiu várias vias, a saber: a dos países em que a religião foi fundamental na luta pela independência nacional, o que criou liames difíceis de cortar entre cultos, Igrejas e política (exemplos: a Igreja ortodoxa na Grécia, o catolicismo na Irlanda); a das sociedades em que existe uma longa lógica de secularização, a qual, porém, nunca ganhou contornos laicistas, como foi o caso de alguns países protestantes (Inglaterra, Finlândia e a Suécia - aqui, foi instaurada uma moderada separação, em 1 de Janeiro de 2000); e a das sociedades em que a secularização recebeu um desenvolvimento militante forte, transformando-se em laicização, tal como se encontra no exemplo francês (mormente desde a III República até hoje), ou se deu em Portugal, sob a I República, ou em Espanha, durante a II República ${ }^{(160)}$.

Se se comparar os textos constitucionais dos 25 Estados que actualmente constituem a União Europeia, nota-se que alguns deles invocam, implícita ou explicitamente, Deus. Relembre-se que, no Reino Unido, o texto fundador - a Magna Carta (1215) - foi feito e outorgado "perante Deus", e que o processo de ruptura com Roma e de formação da Igreja Anglicana fez da Monarquia britânica uma instância religiosa. A constituição que, em Maio de 1949, sob o impacto do trauma do nazismo e da

(159) Para uma análise dos processos de secularização e laicidade na Europa, vejam-se: A. Dierckens (dir.), Pluralisme religieux et laïcités dans l'Union européenne, Bruxelas, Éditions de l'Université Libre de Bruxelles, 1994; Jean Baubérot (dir.), Religions et laïcité dans l'Europe des Douze, Paris, Syros, 1994; Ph. Portier, "Les laïcités dans l'Union européenne: vers une convergence des modèles?", G. Saupin et al., La Tolérance, Rennes, PUR, 1999, pp 303-320. Sobre a realidade específica do Sul da Europa, leia-se Andrea Riccardi (dir.), Il Mediterrâneo nel Novecento. Religioni et stati, Milão, Edizione San Paolo, 1994.

${ }^{(160)}$ Cf. François Champion, "Les rapports Églises-État dans les pays européens de tradition protestante et de tradition catholique. Essai d'analyse", Social Compass, n. ${ }^{\circ}$, vol. 40, 1993, pp. 589-609. 
guerra, carismou os valores fundantes da República Federal Alemã, tem o seguinte preâmbulo: "Consciente da sua responsabilidade perante Deus e os homens, animado pela vontade de servir à promoção da paz no mundo, em igualdade de condições com os demais países membros de uma Europa unida, o Povo Alemão, no exercício do seu poder constituinte, adoptou esta Lei Fundamental". E as constituições da Grécia e da Irlanda, em consequência das suas experiências históricas, estão sob auspícios divinos: a grega, sob a égide da "Santíssima Trindade"; a irlandesa, da "Santíssima Trindade de Quem advém todo o poder e perante Quem todos nós, indivíduos e Estados, prestamos contas, em últimas instâncias". Por sua vez, o texto fundamental da Eslováquia, embora omita a Divindade, nacionaliza e sacraliza os seus mitos de origem, pois explicita a herança de "São Cirilo e São Método", a par do "legado do Grande Império Morávio".

Tudo isto comprova a existência de vários caminhos no que toca a esta matéria: aquele que revela uma ausência quase completa de laicismo, como acontece na Grã-Bretanha (onde o monarca é chefe da Igreja), na Dinamarca (onde a Monarquia se identifica com a Igreja luterana), na Grécia (onde a Igreja ortodoxa está intimamente ligada à luta pela independência nacional); aquele que assenta numa "semi-laicidade" (Alemanha, Bélgica, Holanda, Luxemburgo, Irlanda) que se caracteriza pela existência de um Estado aconfessional, mas que apoia e subsidia as religiões, num clima de independência das Igrejas e de respeito pela liberdade religiosa; aquele que, depois de períodos de laicidade à francesa, pode ser definido como de "quase laicidade" (Portugal, Espanha, Itália), porque, constitucionalmente, o Estado continua a ser religiosamente neutro, embora tenha celebrado tratados concordatários que acabam por privilegiar a religião maioritária; e ainda aquele outro, de cariz "laico", cujo modelo mais consequente e contínuo se encontra, pelo menos desde 1905, na chamada especificidade francesa.

Independentemente do debate acerca da coerência jurídico-formal da suposição de princípios de índole religiosa em coabitação com os que presidem à constitucionalização formal das liberdades fundamentais, convém dizer que, mesmo nos casos de menor laicidade, não se está perante qualquer justificação de ordem jusdivinista ou teológica, pois aqueles surgem dentro de uma cultura secularizada, inspirada nos direitos do homem e na soberania popular. Mas este multiculturalismo - que a entrada da Turquia na União Europeia acentuará -, tal como os demais, 
em vez de extinguir, antes exige a reactualização e o alargamento dos exemplos que, desde a Modernidade, procuraram possibilitar, com algum sucesso, a radicação de formas de sociabilidade e de organização política que garantam a coexistência das diferenças. E, qualquer que seja o conceito - secularização, laicidade, "Estado de direito", "neutralidade" - que denomine a sua reinvenção, esta tem de se inspirar num diálogo (necessariamente crítico) com as experiências anteriores e deve saber reler, à luz dos desafios do presente, os fundamentos que as nortearam. E, quer haja ou não confluência nesta matéria entre os vários países, tem-se por certo que não haverá liberdade religiosa se, simultaneamente, a ordem política não respeitar os direitos do homem e do cidadão (de $1^{\mathrm{a}}, 2^{\mathrm{a}}$ e $3^{\mathrm{a}}$ geração).

Sublinhe-se que, em grego, laós designava a comunidade humana de povo, acepção que foi transformada numa referência ideal, cuja caracterização histórica requer que o homem goze de direitos iguais. Como quem diz: o que vale para todos é de cada um e a realização de cada um, de acordo com as suas convicções, não se pode impor nem obstar à realização dos outros. O termo convida, portanto, ao posicionamento, como premissa, de uma ideia indivisa de povo, sendo este postulado, antes de todas as diferenciações, como raiz da sua própria organização como dêmos e como polis. Consequentemente, enquanto elementos constituintes do laós, os indivíduos não podem ser pensados como entidades antitéticas em relação à sociedade, pois ambas as dimensões (substantiva e formal) se apelam reciprocamente.

Como se viu, dêmos qualifica o povo (laós) quando ele se forma como comunidade política. Diferença que explica que este vocábulo tenha dado laicidade, princípio de direito que liga o poder ao conjunto do povo, enquanto que de dêmos derivou democracia, conceito que, com a Modernidade, passou a traduzir a soberania do povo organizado politicamente. Assim sendo, e como ideia-tipo, poder-se-á sustentar que a laicidade - componente forte da cultura republicana - não diz respeito a qualquer forma específica de regime, pois aponta para uma constitucionalização que tem de instituir o laós como Cidade de Todos (Res Publica).

Em síntese: a unidade do laós, para ser bem cumprida, tem de excluir toda a discriminação, positiva ou negativa, qualquer que seja o seu pretexto (religioso, filosófico, sexual, étnico, social, etc.). Ela dita que a ordem política se organize conforme o seu conceito. Pressupondo a assunção livre das diferenças, a começar pelas de índole individual, é sua função 
criar uma realidade comum a todos. Como modelo ideal de alteridade, ela exige que, em termos positivos, os actos fundadores (ou reformadores) da pólis respeitem a liberdade e a igualdade na diversidade; mas, em termos negativos, visa impedir que uma parte (mesmo quando sociologicamente maioritária) possa gozar de privilégios e ferir a liberdade das outras, logo, dos indivíduos que, bem vistas as coisas, são o ponto de partida e devem ser o ponto de chegada de todos os tipos de mediação sociabilitária.

É certo que, hoje, se questiona o enlace existente entre o conceito de laicidade e o de cultura republicana, destacando-se o facto de esta última ter como objectivo maior a relevação do indivíduo-cidadão dentro de um contexto emancipatório excessivamente crente no valor universal da ideia de progresso e empenhado, não tanto em respeitar as diferenças, mas mais em as fazer diluir na almejada harmonia do consenso nacional. Algo que as diversificações contemporâneas e as novas modalidades de realizar o direito à cidadania estarão a pôr em causa. Seja como for, deve lembrar-se que o universalismo dessa cultura, nas suas versões mais antijacobinas, também procurou compatibilizar-se com o particular, como se prova através da força das suas tendências descentralistas e federalistas.

Numa época em que a secularização fez brotar e crescer a concorrência no "mercado religioso", que os movimentos migrantes tornaram ainda mais complexo e potencialmente mais conflituoso, ter-se-á de ter consciência de que o que está em causa é demasiadamente importante para a humanidade do homem para ser entregue, sem mais, à luta de todos contra todos. $\mathrm{O}$ que reforça a necessidade de um pano de fundo comum, democraticamente legitimado, que garanta, em coexistência pacífica e integrada, a coabitação de diferenças, mas no respeito daquilo que a possibilita. Caso contrário, e como ensina o melhor do que se pode colher das lutas pela secularização e pela laicidade, abrir-se-ão, sem resistência, portas ao egocentrismo fundamentalista, ou a fragmentações anómicas, intolerantes e "tribais", ou, ainda, ao predomínio de maiorias interessadas, tão-somente, em fazer perdurar os seus velhos poderes.

O reconhecimento e a valorização das diversidades, objectivadas como multiculturalismo, são condições nucleares para se corrigir as concepções (e práticas) demasiadamente abstractas sobre o indivíduo e a natureza do contrato social. Porém, as suas entificações também podem conduzir a uma monadologia ensimesmada e autárcica, não obstante ser igualmente verdade que a pressuposição de atitudes de assimilação - herança de um certo Iluminismo - tende a diluir, aculturar ou destruir o que 
toma por particular, em nome de uma ideia de homogeneidade realizada como in-diferença.

Ora, apesar do cariz aparentemente irredutível da antítese entre o universal e o particular - afinal, uma velha questão-, ambos, para serem pensáveis, têm de se exigir, conquanto o segundo, não raro, tenha sido visto como meio ou epifenómeno que o primeiro utiliza para o ultrapassar (tradição hegeliana). Se esta concepção serviu para "esconder" interesses eurocêntricos, o certo é que ela também é arma (porque promessa incumprida) a que os oprimidos (em particular, as classes dominadas, os povos colonizados, as minorias de todo o tipo) recorrem para se libertarem. Daí, o seu inevitável correlacionamento, aposta que tem de ser alimentada por uma luta constante, sobretudo dos que, ultrapassando o conceito clássico de tolerância, procuram encontrar "passagens" e levantar "pontes" de duplo sentido dialógico - jogo de espelhos que vai produzindo identidades e diferenças -, ou erguer "casas comuns" sem senhorios ou inquilinos, ainda que de alicerces permanentemente ameaçados. O que obriga a um contínuo exercício da razão crítica (e autocrítica), de modo a que se consiga ir construindo novos elos sociabilitários que soterrem a insociabilidade igualmente ínsita à natureza humana (Kant), num inconcluso combate da cultura contra a barbárie. $\mathrm{E}$, como são sempre precárias as fronteiras entre hos-pitalidade e hos-tilidade (Miguel Baptista Pereira), só uma prática que saiba dar vida à simultânea pertença de cada indivíduo a diferentes esferas de participação cidadã (grupal, regional, nacional, cosmopolita) poderá legitimar e garantir o cumprimento de ideias e valores de vocação transversal capazes de abrir janelas para que a consubstanciação política do laós não fique menorizada pela sua redução a éthnos. 